\title{
八丈島の恙虫と恙虫病の研㶢
}

\section{Studies on Tsutsugamushi and Tsutsugamushi- disease of Hachijo Island}

\section{上 野 庸 治 ${ }^{2}$ Yoji Ueno}

\section{まえがき}

八丈島は行政上東京都に所属し，東京の南方約 350 $\mathrm{km}$ 飞位し，その面積怡 69.172 平方 $\mathrm{km}$, 人口約 1 万 2 干学算する太平洋上の孤島であるが，その気侯は亜熱

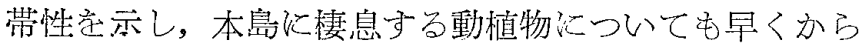
学界の関心がよおられていたてと施周知の通りである。

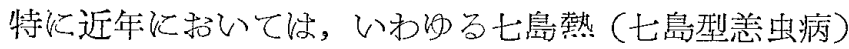
の発見や，数腫の極めて重要な恙虫の棲息が知られて医

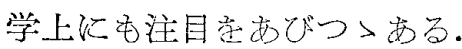

筆者心1949年来本島に存住して患者の治潦火従事のか たわら，本島の風土病について検索字す〉めていたが， 1950年以後，伝研奇生虫研究部貣傜よる本島の恙虫の研 究に協同し，案た東京都七島熱委員会の研究活動光分担 して本島に招ける恙虫及じ恙虫病の研究军行つて来た。 特に1953年から東北大学，黒屋政彦教授及心゙伝研佳从学

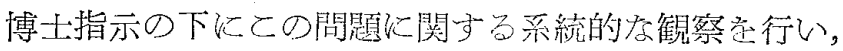

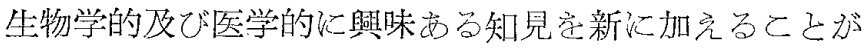
出来たので，その概要学し〉に報告することこした，

\section{管 1 編 凡文地方の壴虫の研究}

\section{更研究経過}

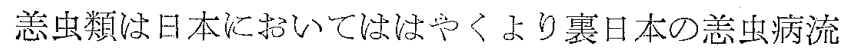

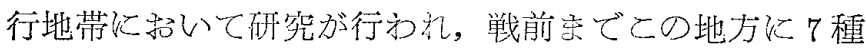
のツツガムシ科のダニが記録さ礼，民のラちアカツッガ ムシ Trombicula akamushi (Brumpt, 1910) が桇介種

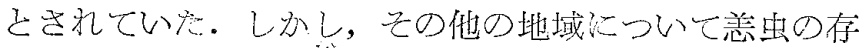

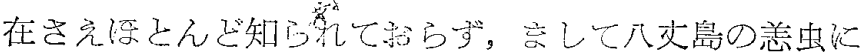

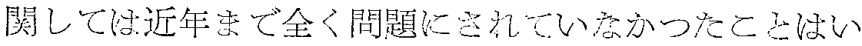
弓宋ですない。しかし，八文地方（八文島，小島，青厅

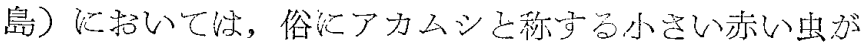
夏炕発生し，はげしい皮疹起すこしは住民の間で店く 知兄て招り，㤢从，加納（1950）心こ㣗堂ナンヨウッ

1) 本稿的印刷実費著者負担特別原稿

2)八西悬三根䛦療所
ツガムシ Trombicula wichmanni (Oudemans, 1905) 己決定した。 その後佐々，寺㫕，加納 (1950) 峙 3 月初 旬の調查に招いて，八文の野监及び野鳥からタテッッガ ムシ，タミヤツツガムシ及びバーンズツツガムシの3 種 省見出し，冬期飞す色↔な種類の恚虫が発生しているこ 乞学明らかにした。

筆者经当地方に冬期に発疹性の疾忠が多発するとと圭 経験し，以灾くよりその本態について検討定行つていた

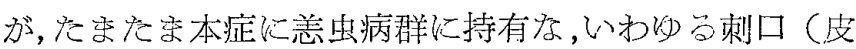

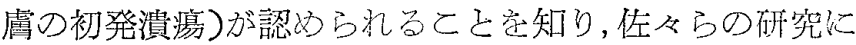
協同して1952年12月吕らこの地域の恙虫及び恙虫病につ いて検索寺す〉めた。乙の結果，本病流行期にタテッッ ガムシが㕕く本島に多発しているとと省認め，他面，東 宗都七島熱研突委員全（委員長 新井養老博士）の協同 研究によつて当地方の発疹性疾患が恙虾病の1種である

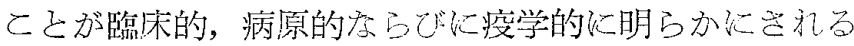
そ及んで，本種がこの媒介種しして注目されるうになつ ti.

その後，佐队ら $(1952 ， 1953)$ の八灭島地方の恙虫の 分類学的研究や，鍮木ら (1953), 林ら (1954) の生態学

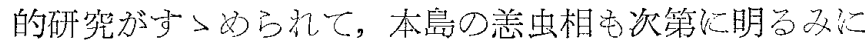
亗さ礼て来た。

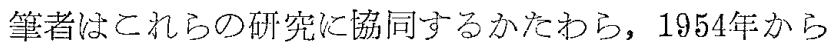

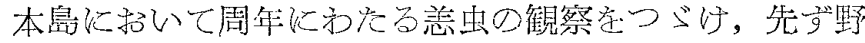

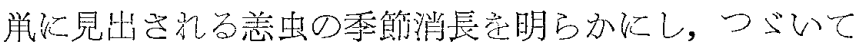

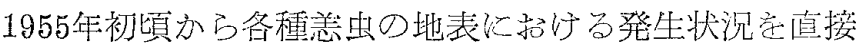
飞検出してその季節消長芭しらべるととに成牛した。さ

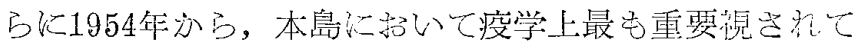
いる $T$. scutellaris が地表に焦団しして出現してくる現

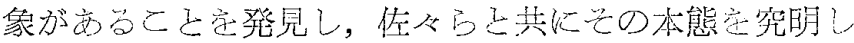

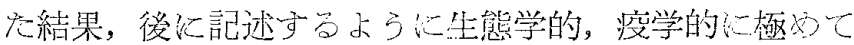

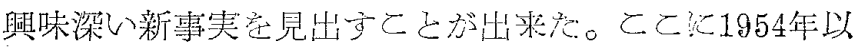

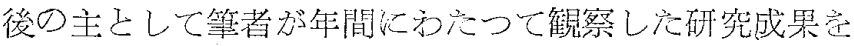
委しめて報告子る。 


\section{II 八文地方に見出ざれた密虫の種類}

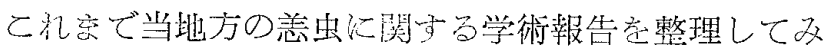

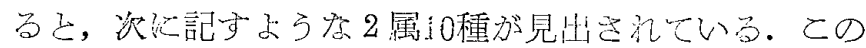

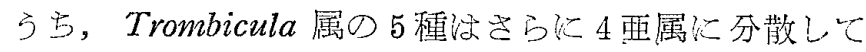
招り, Neoschöngastia 属の㐫のが 5 種類も記録されたて と己相まつて，本島の恙虫相の特色定なしている．乙录

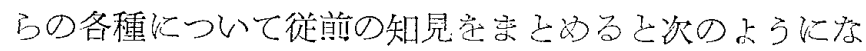

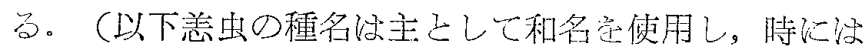

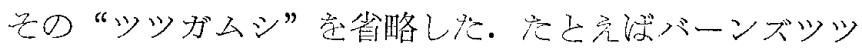
ガムシ定バーンズとした場合するる。）

\section{Trombicula (Leptotrombidium) scutellaris Nagayo} et al., 1921 タテツツガムシ

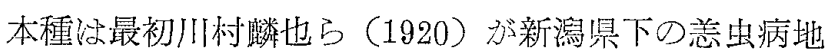
帯で見出し，B型となづけたもので，翌年に長与ら(1921)

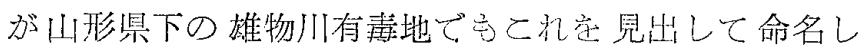

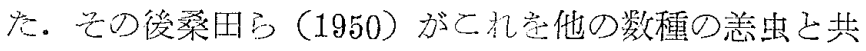

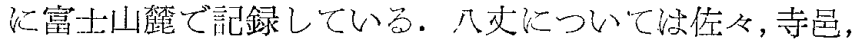
加納 (1950) が1950年 3 月と5月化クマネズミ、ドブネ ズミ，アカコツコなどから採集したのが最初である。本

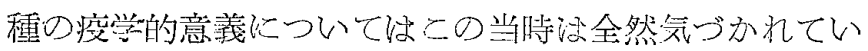
なかつたが，1951年12月の七島熱研究班尤子る第1回の 調査にさいし，いわりる七島熱つ煤介種ではないかとい

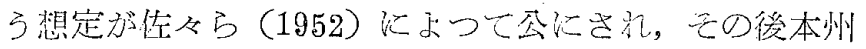
各地の秋型恙虫病の発生地にも見出されて広く七島型恙 虫病の伝播種已考只られるに至つたもので方名。本島に

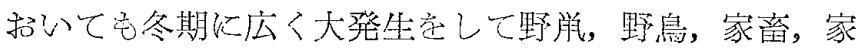

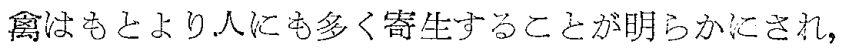

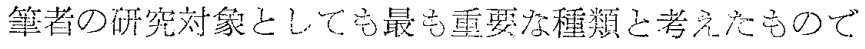
ある。

本種は分類学上 T. akamushi 已回じ坐属隹し，乙

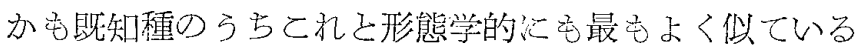

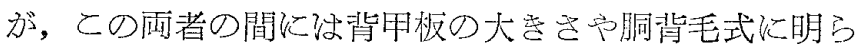

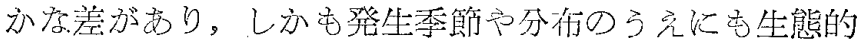
な相違忍認められるので，別種已判断される。

\section{Trombicula (Leptotrombidium) pallida burnsi}

Sasa, Teramura et Kano, 1950 バーンズ ツッガムシ

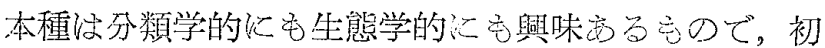
め原著者炕小り新種として報告されたが，現在では佐 «，柿，田中（1955）により pallida の里種已して报わ れている。背甲板なざの性質な pallida と漂ざ一致する が，胴背毛の数が日本の各地で採集された pallida に比 し有意な差定示し，原則こして $2 ， 10 ， 10 ， 8$ の配列学 示している点で区別される。篗者绾1954年12月八丈島の

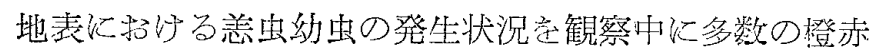

色美是するタテッツガムシ約虫の集団の中に白色の幼虫

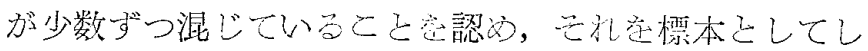
巨ベをとしろいずれるバーンズツッガムシ幼虫であるこ

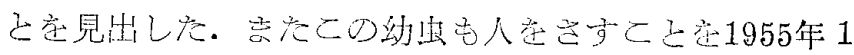

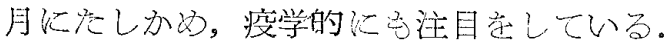

\section{Trombicula (Neotrombicula) tamiyai Philip}

et Fuller, 1950 タミヤッツガムシ

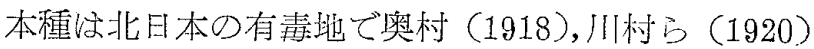
により見出され，終戦後に原著者らにより命名されたも のである放，八大島飞招いて佐々，寺邑，加納(1950)

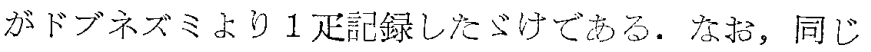
伊豆七島の新島纪永いてはトカゲ及ずドブネズミから見 出さ礼てい当(佐从ら，1953).

\section{Trombicuia (Toritrombicula) hasegawai Sasa,}

Hayashi et Kawashima, 1953 八セガワッツガ ムシ

1952年 9 月飞八丈島及び小島ふら発見された恙虫で， これまでは本島以外炕見出さ机ていない，筆者汶との 米吸着幼虫が本島の飛行場周辺などの山柿で夏にナンヨ ウッツガムシなごにまじつて地表に出現すること見出 し，その生態についてす検索赾すかて来たが，乙の種 類は鳥に選択的炕寄生するこいう点で注目に值するるの である。

\section{Trombicula (Eutrombicula) wichmanni}

(Oudemans, 1905) ナンヨウッツォ゙ムシ

1948年 7月に佐々，加納（1950）飞小り八丈小島汇記 録さ敞て後に八灭島，青方島にも夏期に多数に発生する

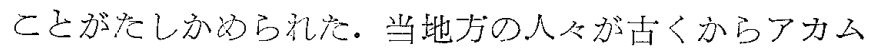

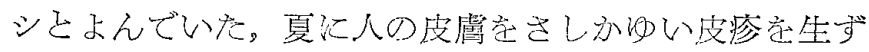
る小虫がこれでする。しかし，当地方炕注しれにさ入机

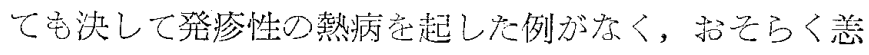

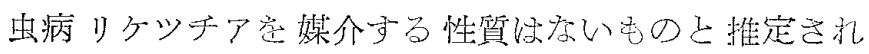

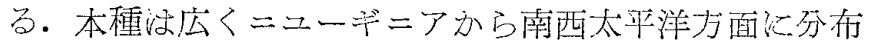
し, 宿主の範团が広くて, 本島です人, 野学, 各種の野 鳥，オカダトカゲ等炕寄生して括り，その発生期間注主 に夏で㐫る。

\section{Neoschöngastia 属 (トリタマツツガムシ属)}

本島红注 $N$. posekanyi Wharton et Hardcastle, $1946 ; N$. americana solomonis W. et H., $1946 ; N$. carveri W. et H., 1946; N. monticola W. et H., 1946 ; $N$. paenitens Brennan, 1952 の 種がすでに見出されて

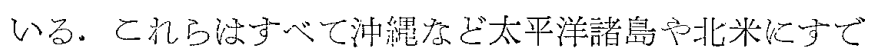

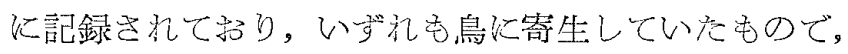
本島ではアカコッコ、キジバト,イソレヨドリなぞがこの 主要宿主であつた．とれらのうち少くも初わの 4 種注八

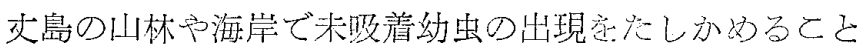


が出来た。

今日末で本島で見话き行恙虫は以上の10種である が，乙の掭か心将来新しい種類が迫加される可能性怡 大きい。しふし，この恙虫相定他の地域のものと比べる と次のよら存著しい特徽があるここに気づく。

1. 本島に注日本全般，特飞関東地方に多いフジッッ ガムシ，キタサトツツガムシ，ガーリェピアツツガムシ

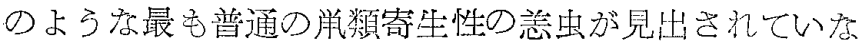

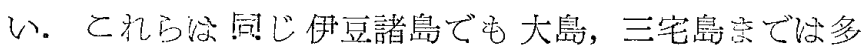
数に繁殖しているが，さらに南力位する当地力に発

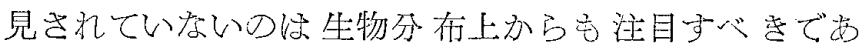
る.

2. 本島飞捛げるデツツガムシの晎学な大発生上江 の地域分有の広沉なと已《他の地方汇類列字品ない現象 で，七島型恙虫病の多発己相事つて当地方の恙虫相の最 大の特色である。

3. 当地力火はナンヨウッツガムシのような南洋系の 恙虫が多く繁殖していると己も注目すべきで，乙机は 本の本土に惊末だ採集されたここが疗く，日本の他の地 域乞しては九州南方の離島（北原，1952）及び新島（熊 田引，1955）火見计さ㣗ているの名て，乙の事卖は本島 の熱帯的自自然環境这物語るものであるう。

4. 八セガワツツガムシやトリタマツツガムシ属のよ うな鳥奇生性の恙虫が豊富に見忛されていることむ持徴 である.しかし，奧寄生性のものが夏はナンヨウッツガ ムシ，冬化タテッッガムシとそれぞれ1種しふないのは 本上と著しく異る点である。

\section{III 恙虫の未吸着幼虫の生態}

恙蛙科のダニの生活果以原則乞して卵，幼虫，若虫，

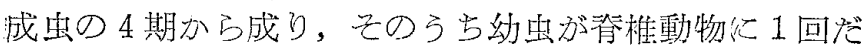

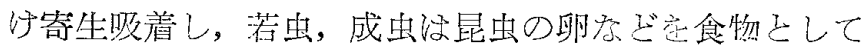

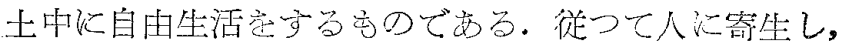

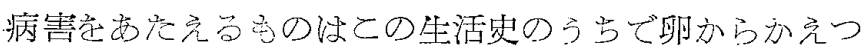

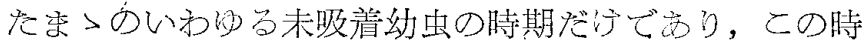

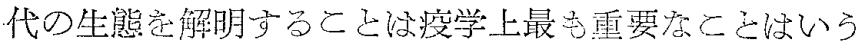

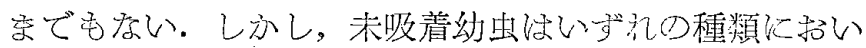

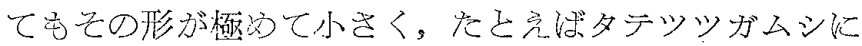

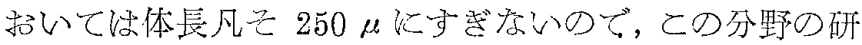

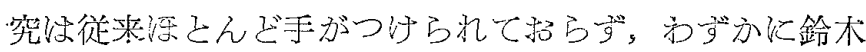
b (1953) 应中心以伝研寄生虫研究部で行われた一連の

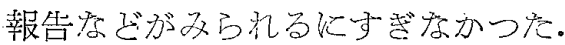

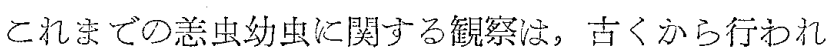
た野単なざの宿主学捕えて气の体から捕集する方法さ， 鈴木らの用いた地表にベークライト板宗じを招いてとれ 比い上る個体定集的る己いう間接の力法が主要学もの

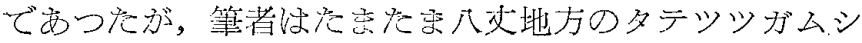

はその棲息密度が極的て高いこい弓実状㑡してこの発

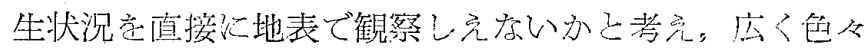
な地域について梌討学す〉沙た。

その結果，タテッッガムシは八主の有さんざ全般に

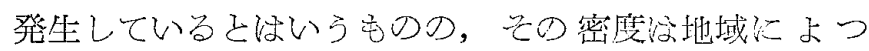
て著しい差があり，特筆者の見出した飛行場北側の山

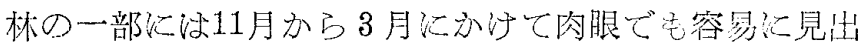

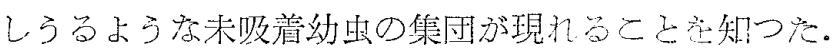
さらにしの地域に虫夏にもナンヨウッツガムシ，八セガ

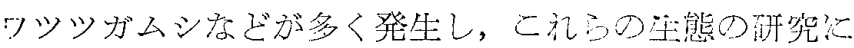

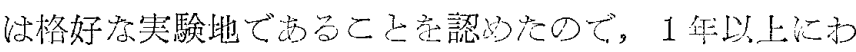

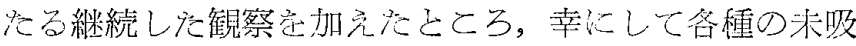

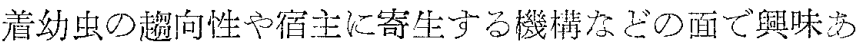

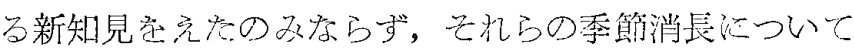

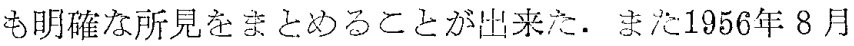

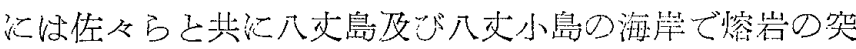
端传数種の恙虫未吸着幼虫が出現するこ上発罗し，こ れらが従前の研究で特にイソヒヨドリに笴生高認的られ

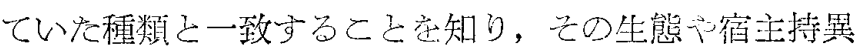
性の本熊定明らか飞するここが出来た。

\section{A. テッッガムシについて}

\section{1. 自然界における焦可出現性と宿王附着機桡}

等者行1954年11月の発乐期から八丈島谷地の山林中で 签岩なごの突端に本種幻虫が集団こして出現して来る現 泉が多られるのに気がつい\%。乙炕，本種幼虫の発生 密度が高い地带に人が入つてゆき，し涩らく地表学及つ わていたり，撘岩の加ら老拾いるげて眺めていたりす る己，それ栾で扎なざに潜んでいた幼虫が斯意出して次 第に高い部位の乫端なざ集り，肉眼です容易に識別し

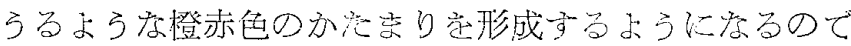

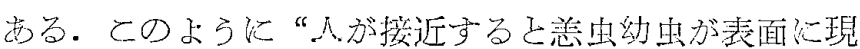

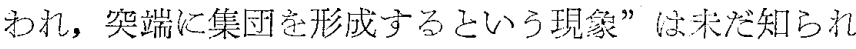

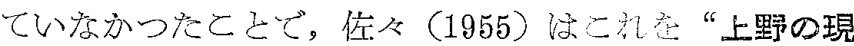
腺”之呼称した。

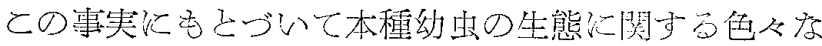

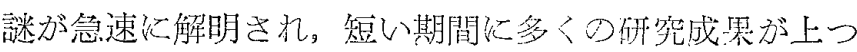

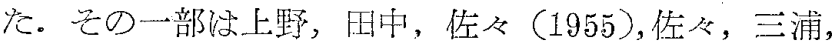
田中，上野（1955)，田中，佐々，上野（1955）なごの報

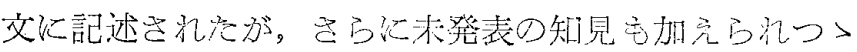
あり，こ〉にその概要学述心゙るとととする。

この発見がもたらした第1の研究上の便宜は未吸着幼 虫が多数飞採集され，淂外及び実験室内で自由に供試し

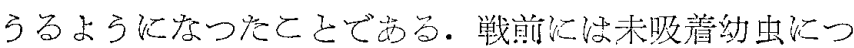

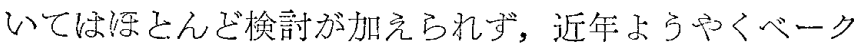

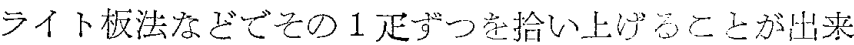


るようになつ岸が，ての集団出現性の発見により未吸着 幼虫の数千，数万を筆でガラス器内にはらい入れるとる

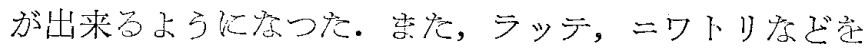
この集団に接着させて，実歌的に多数の幼虫定寄生さ

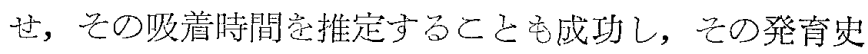
の解明堵しい進歩交あた光を(第1，2表).

第1表 ダテッッガムシ幼虫のラッテ笴生開始後に 耳内にみられる数の時間的推棃(上野, 田中) (1955年 1 月 30 日，八大島山林，14時上り 16 時まで 2 時間 放置 15 時基準とす)

Transition of the number of larvae of Trombicula scutellaris in the ear lobe of rats by the hours after exposures to the infested areas in Hachijo Island.

\begin{tabular}{c|rrrccl}
\hline \hline \multirow{2}{*}{ 鼠番号 } & \multicolumn{7}{|c}{ 寄生後の時間経過 } \\
\hline 1 & 2.5 & 18.5 & 23 & 27 & 42.5 & 55 時閒後 \\
\hline 1 & 31 & 43 & 38 & 34 & 0 & 0 \\
3 & 63 & 103 & 68 & 48 & 0 & 0 \\
4 & 62 & 129 & 127 & 47 & 5 & 0 \\
5 & 125 & 216 & 118 & 53 & 7 & 0 \\
\hline 訫 & 341 & 593 & 467 & 238 & 18 & 0
\end{tabular}

註. 鼠耳内の恙虫数はルーペで直接にかでえれ。上の 実験により約18時間後が最高で, 以後逐次減少し,

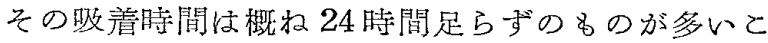
そ孝知る。

\section{2. 集落形成性とその機桡}

自然界において常時は物加げに潜九でいる幼虫が，人

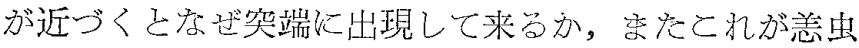

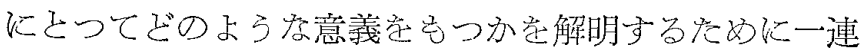

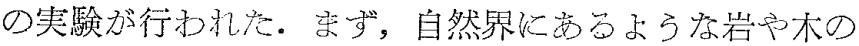

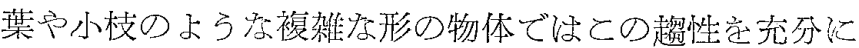

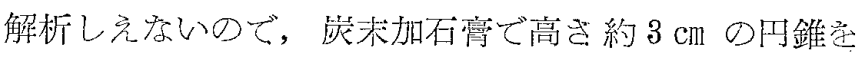

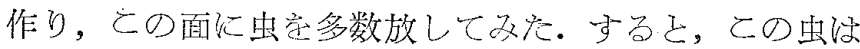

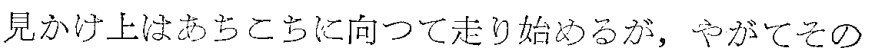

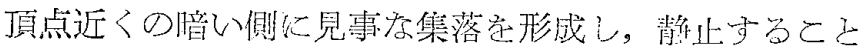
分分つ\%。即古，単独でいる虫が刺战される之“反越地 性”乙“后䞶光性”学示しながら運動し，円錐面飞招い ては必然的に頂点の暗い側飞集当。そ!て。何正かの虫

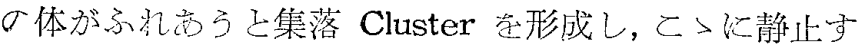

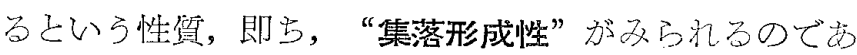
る.

この集落定ガラス器内に招さめ, 外気示ら遮断し, 湿度 の高い状態に扔く已虫々いつまでも静止しているが，乾 燥やカビの発生などのない限り長期間座存して，ての>

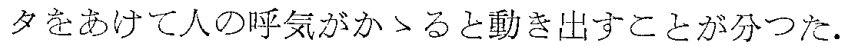
1955年 1 月に採集した幼虫の集団虫 6 月末末で生存して

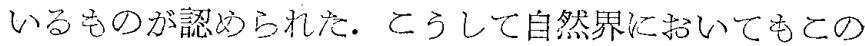
蜼地表の物体の頂点近くの物办代に平時集落を作つ て静止していることが分り，これは虫がエネルギー定節 約し，乾懆にたえて長く生存するために湛だ好都合な性 質であるこ己が理解された。

\section{3. 呼気中の炭酸方スによる興䳽現象}

次に，自然界で人が近づくこなざての虫が運動学開始

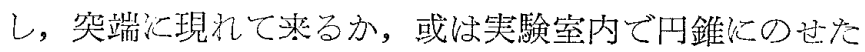

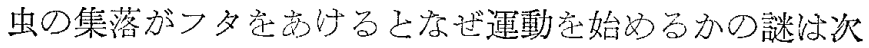
のような実験で明らか飞された。しのようなさいの刺战 要因已して振動 (音), 光の変化, 輻射熱, 風, 呼気の湿

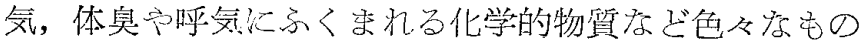

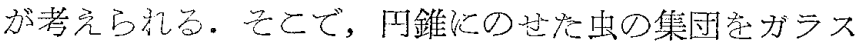

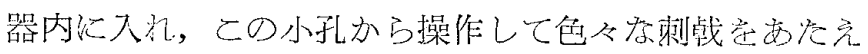
て员たところ, 音, 光, 熱, 湿気, 風なごの物理的要因

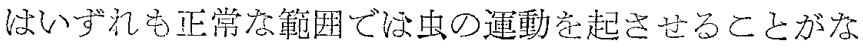

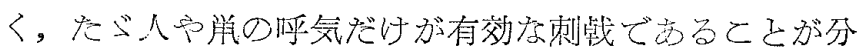
ste.

次に呼気中の有效因子省しらべるた的にガラス容器に

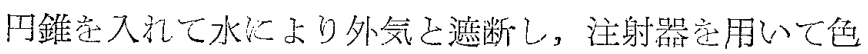
々な気体安しの中圦てみを。その結果，アルコー

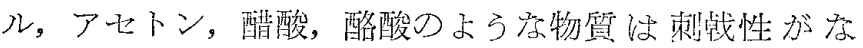

第 2 表 タテッッガムシのラッテ吸着時間の観䕓

Aは附着させてからの経過時間

B文飞の観察期閒の時間数

Cは覾察時間中K淽腹落下した恙虫数

\begin{tabular}{|c|c|c|c|c|c|c|c|c|c|c|c|c|c|c|c|}
\hline A & 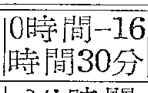 & & $: 3$ & $1: 0$ & $4: 30$ & $5: 0$ & $25: 30$ & $1]: 5$ & $\overline{43: 2}$ & $3: 5$ & $44: 2$ & & $5: 30$ & & $\begin{array}{l}3: 10- \\
9: 30, \\
\end{array}$ \\
\hline B & $\begin{array}{c}16 \text { 時間 } \\
30 \text { 分 }\end{array}$ & 5,00 & 2,30 & 0,30 & 0,30 & 0,30 & 16,20 & 1,30 & 0,30 & 0,30 & 5,30 & 1,50 & 13,50 & 7,40 & $\frac{16: 50,}{16,20}$ \\
\hline 鼠 I 号 & 0 & 0 & 0 & 2 & 5 & 1 & 8 & 2 & 7 & 8 & 8 & 9 & 4 & 1 & 0 \\
\hline II量 & 0 & 1 & 11 & 19 & 4 & 5 & 27 & 12 & 24 & 1. & 13 & 8 & 1 & 0 & 0 \\
\hline III 号 & 0 & 0 & 0 & 0 & 3 & 0 & 66 & 3 & 2 & 5 & 29 & 11 & 3 & 0 & 0 \\
\hline
\end{tabular}




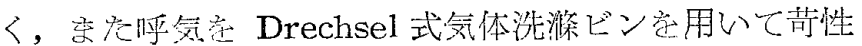
ソーダ液, 稀硫酸, 水, アセトン季ぞで洗つたもの送

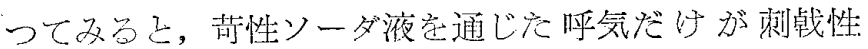
学失い，他活を已の呼気之同様の作用があることが分つ た。即占，有效物質实アルカリ吸収性のものであるてを が明らか飞れさた。

呼気中のこのよらな物質として先ず考光られるのは揮 発性の酸性物質と炭酸がスであるが，後者がその本態で

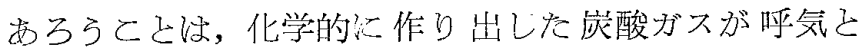
同程度の微量で虫の運動学ひき起す作用省もつととで明 らかにされた。この装置で呼気で 125倍末でうすめた気 体の5 cc党西たえてもな和有效であるが，さらにてれ当 5 倍にうすめたものは刺战性学失うこと, 孷酸ガズ学先 ず空気で呼気と同程度の $4.5 \%$ 亿うずめた気体る同じ程 度の刺㦸性をもつと之から，呼気中には炭酸ガス以外に これ以上有效宗刺㦸物質生存在しないであるう己推定し た.

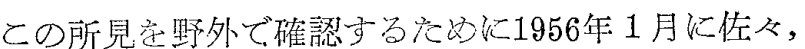
三浦と共に八丈島の山林で次のょうな实験学行つた。

a. Drechsel 式気体洗㩖ビンに 200ccの飽和バリッ 卜水老入れ，笑験者（佐ふ）が呼気をゴム管でての中に 吹きてんで若酸ガス省吸収させな゙らタテッツガムシ幼 虫の発生場所の山林に入つて四常, 前日の観察で多数の 虫が現れるととをたしかるた岩定見回つたが，ぞれにも

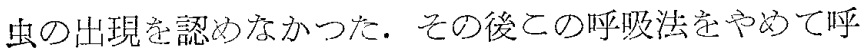

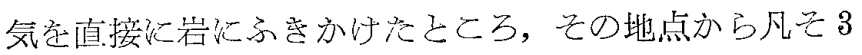
$\mathrm{m}$ の範团の岩角《多数の虫が出現した。

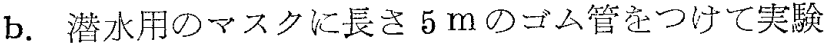
者 (上野) がこれ定装置し，呼気が管等通じて凡そ5 m はなれた場所以吹き出されるようにして風上から山林に 入つて岩堂検査した。この場合もたと充実驗者が接近し

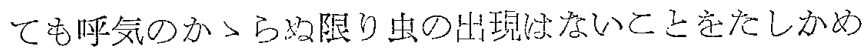
た。この2つの方法で実験者の呼気 (欢てその中のバリ ッ下結合性の物筫）党さえざりながら虫の潜んでいる岩 を手で拾い上げても，上下学さかさ恋にしても，票を振

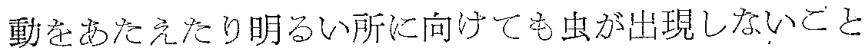
学諗好。

以上の上うな実験のくりかえしによつて,タテッツガ

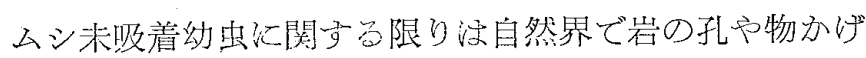
に潜しで静止している虫が罢だ僅分の空気中の炭酸ガス

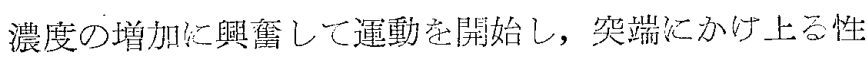

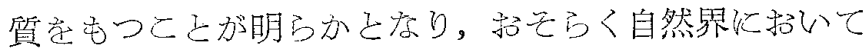
它宿主の接近定主としてその呼気中の炭酸がスにより認 知して笴生の機会定つかむるのでらるこてが推定され た。こうして恙虫幼虫の宿主熔生するをで機構の少く

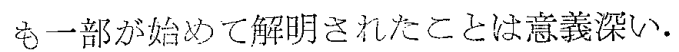

\section{B．夏型恚虫の類種について}

八丈島地方注型(冬に幼虫の発生ずうの)のタテ ツッガムシ，バーンズツツガムシなどの㴗か，夏に幼虫 の発生学双るナンヨウッツガムシ，八セガワツツガムシ 及びトリタマツツガムシ属 Neoschöngastia の数稙が見

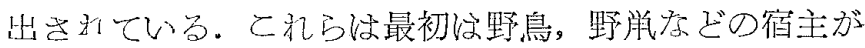
調べられて，その体表《寄生したもの分採集されたので 西るが，筆者岵1955年夏より八文飛行場の北側の山林に ナンヨウ，八セガワ，パェニテンスの3 種が発生してタ テッツッ゙ムシの場合と同様纪地上の岩や落葉なぞの突端 にそれらの未吸着幼虫が出現して来る事実定たしかか た。亦た1956年 8 月には佉从，三浦らと共飞八交島及び 八丈小島の海岸附近の熔岩の㠾端飞恙虫未吸着幼虫が出

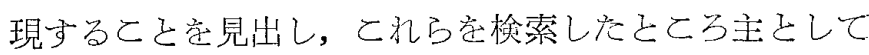
ソロキン，ポセカ二の両種であるこさを知った。乙虬ら の生態炕関する詳細经佐々，田中らと協同で別に報告す る予定であるが，てとに主として筆者の相当した研究分 野の概要学記述したい.

\section{1. 夏型恙虫幼虫の地表分布}

令型のタテッツガムシが八丈島に扮いては非常に広沉 な地域分布学示し, 部落内, 耕地, 山村などあら西地 帯に見出されるのに比して，夏型のものはいずれもその 地域分布が限局されているのが持色である。たとえば当 地方で一般の人からアカムシさよばれているナンヨウツ ツガムシ海每同じ場所の，特定の山林や耕地にだけ発

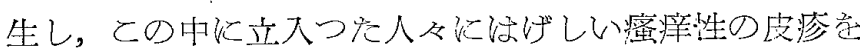
生ずるこ己は広く知られて招り，タテッツガムシのよう に部落内や一般の耕地などにも見出されるととはない。

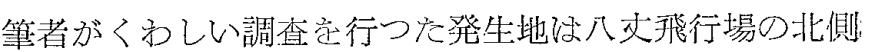

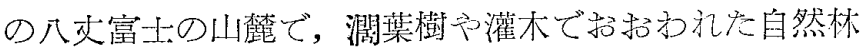
の地帯で, 大小の火山䃯が堆積している. この地域に入

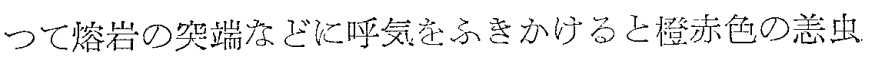
未叫着幼虫が一つの岩について数正示ら数十正ずつ（同， じ地域で冬にみら礼るタテッッッガムシの場合よりずつを

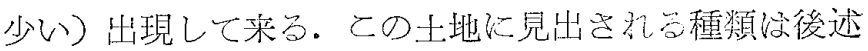
ずるよゔンヨウ，八セガワ，パェニテンスの3 種で 娄つた。

1956年 8 月の八丈島及び八丈小島の調查ではさらに海 岸の熔岩地带にも岩の突端などに恙虫が出現すること觉 知つた。筆者らのしらべた八丈島の三根海岸では波打ぎ

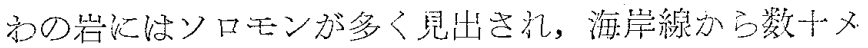

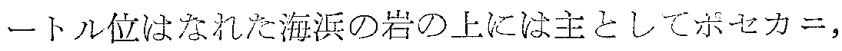
八せガワの耐種が採集された。1個の岩についてその乫 端に出現した恙虫の数怡最す多い場合でる79走にすぎな からた. 
1956年 8 月の八亦小島での調査飞预いて々鳥打部落の

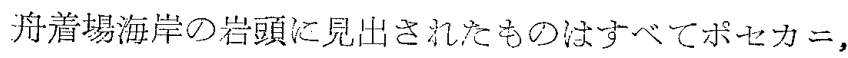
とれ办ら部落に登る道の台地の上の墓地で注ナンヨウ， 八セガワ，ポセカ この3 種, 部落の北辺の畑地で汸ナン ヨウの 1 䝵だ採集された。

こうして，夏型恙中の場合はとの発生地が全般として 特殊な地域に限局されているばかりでなく，山林，畑 地，海岸，なぎさなごの環境の相違汇伴う各種類つ地域 分布の差が認內られたと上纱興味深い。

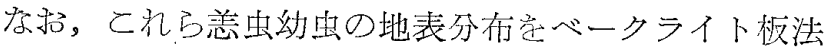
によつて林ら (1954) がしらべた成績では，タテッッガ ムシ幼虫情極めて不均一の，集中型（非ポアッソン型） であるのに比して, 夏型のナンヨウッッガムシの場合に

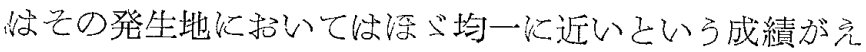
られている。即与，前者虫集落远形成方文性質が放るた 动に一局所飞甚だ多数が見出されるのに比して，後者活 各個体が単独に棲息する傾向が方ることによつててのよ らな差が生ずるものと推定される。

\section{2. 夏型恙虫の活動性}

1955年夏に田中らと，1956年夏飞佐々ら已協同で検窈 几成績では，てれらの夏型恙虫の各種幼虫はタテッッ

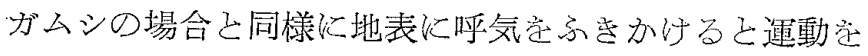
開始して岩の小孔や物かげな゙から出現して来るこさ， 炭酸がス学吹きか行ても同樣の反応学示すととが明らか

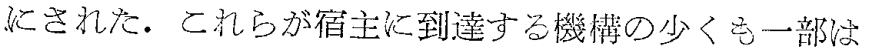
このようにタテッッガムシなどと共通しているようであ るが，その生態については次の上うな点でかなりの相違 が西ること肪分つた。

a. ナンヨウツツガムシ，八セガワッツガムシ及びト リタマツツガムシ属の各種福タテッツガムシのように平 面传露出した集落定形成して静止することがなくたを

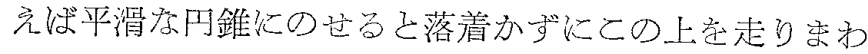
つて湑とんご全部が転落してし宗う。しかし，円錐の頂 点近くに多数の小孔娄作つて招くと，占上引ざ自然界の

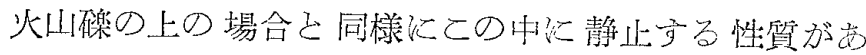
る.

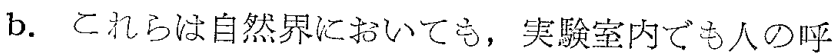
気や化学的飞作つた孷酸ガスに反応して，小孔の中潜 んでいるものが活動学開始し突端にか心上る性筫学もつ が，タテッツ永ムシの場合より鈍感で，呼気き直接に吹

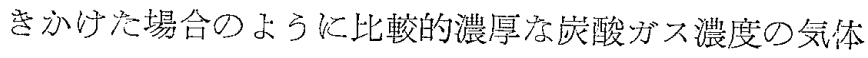
Kのみ反岕宗す。そして，少くもナンヨウツッガム

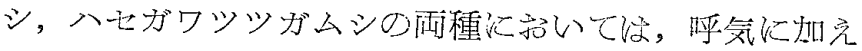

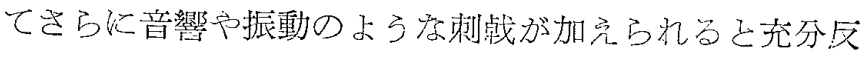
応がみられなうで饬る。即与，てれらの種類の興皞機構 はタテッツガムシの場合に比して複䧴なむのがあり，そ

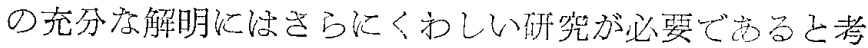
六口机る。

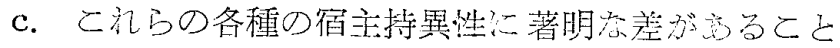

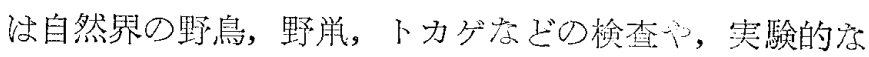
寄生性の研究で明ら亦にさ机た。即ち, 八七ガワツッガ ムシ及び各種のトリタマツツガムシ属のむの泾自然界で 注鳥だ计加証明されて招り，同じ地域で捕えられ视野 学，トカゲなぞから検出さ扎たととはないのに反して， ナンヨウツツガムシはュのすべて飞見出され，人にも寄

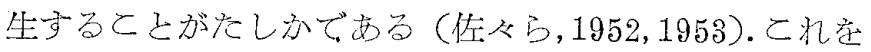
実駼的にもたしかめるため和1955年夏に田中らと，1956

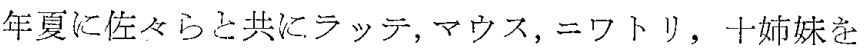
用い，乙れらをとモで結んで恙虫発生地に放したり, 恙虫 幼虫の出現した岩頭なざに手でつかまえながら接着した

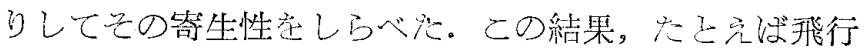
場北側の山村でばナンヨウ, 八セガワ,ポセカ 二の3 種の う亏, ナンヨウはラッテ，ニワトリ，十姉姝のいずれに

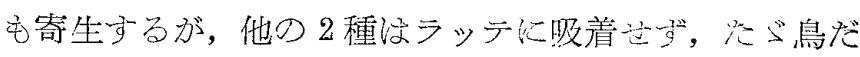

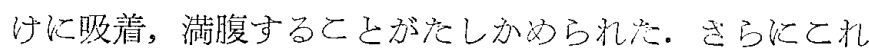

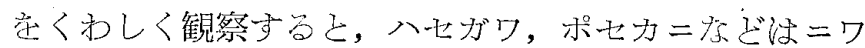

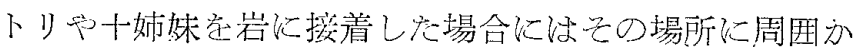
ら集つて来て，脚や羽毛化積極的化よじ登るが，ラッテ では集つて来ることがなく，たとえその脚や毛比登つて

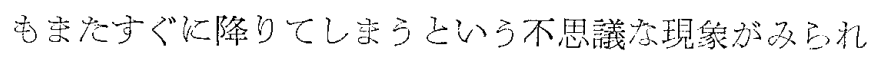
た。ぞうしててのような差が生ずるかについては未だ充 分飞明らかではないが, 已记らの恙虫の宿主巽択性が宿

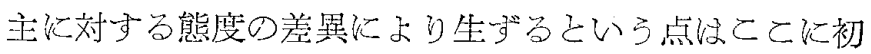

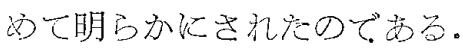

な抬，従前から各種の野鳥のうちイソヒヨドリのみが 特異なトリタマツツガムシ属の種類定寄生子しるている

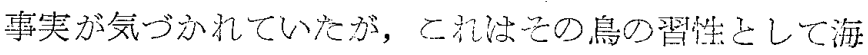
岸の岩の笑端在とじ歩くという点にその原因があるとと

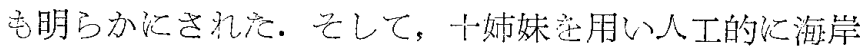
の岩頂以京れさ热るとし沉らのトリタマッッガムシ属の

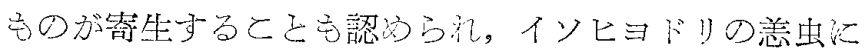

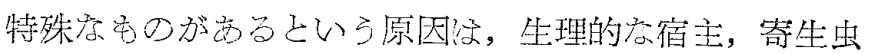

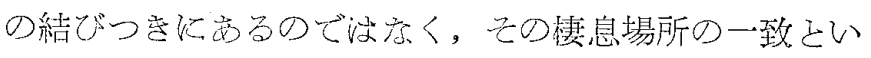

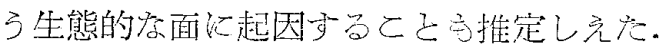

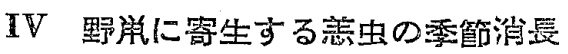

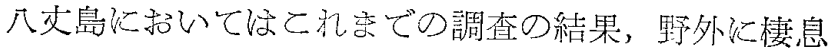
している学類に汸ドブネズミ Rattus norvegicus，クマ ネズミRattus rattus, ハツカネズミ Mus musculus の 3種しか見出されて招らず，本比普通のアカネズミ Apodemus speciosus (三宅島望で分布) やハタネズミ

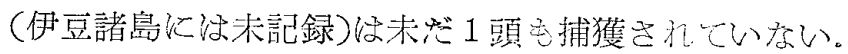


このう马,ドブネズミが屋内焉をより，部落内，耕 地，山林なざ飞広く大繁殖定して優樊種で方り，クマネ ズミ汇人家附近の野外や山林で全く野生化した生活学し ているものも古るしとも特徴である。そして, 恙虫の宿 主としてもこの両種が主要なむのである。

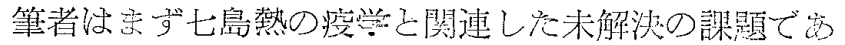
つた八文地河の恙虫，特にタテッツガムシ幼虫の季節消

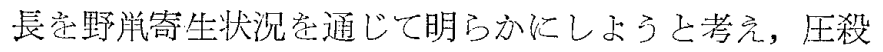
式捕能器忞用いて三根部落附近の10力所定えらんで定期

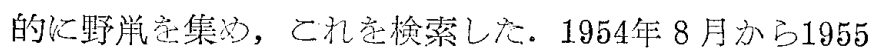
年10月までの1年 3 カ月にわ在る期間に捕獲された野学

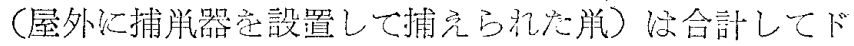
ブネズミ 185頭，クマネズミ44頭で，恙盘深 T. scutellaris の1種の文, 合計3,215 㱜であつた。こ礼らの谷

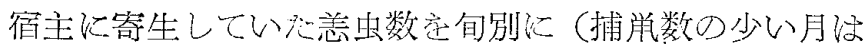

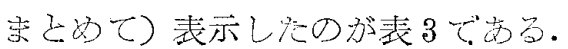

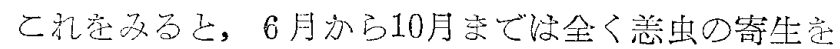

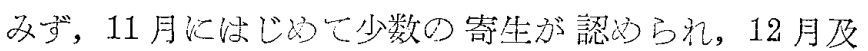

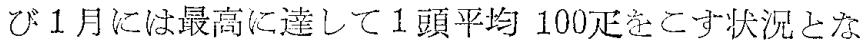

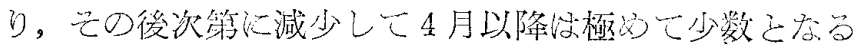
こ己が明ら亦上なった。即ちこの地域に括いては，タテ ツツガムシ発生が典型的な冬型定示与ととが分つた。

第 3 表 野武にみられる恙虫幼虫の季節消長

Seasonal occurrence of Trombicula scutellaris on field rats in Hachijo.

\begin{tabular}{|c|c|c|c|c|c|c|c|c|c|c|c|}
\hline \multirow{3}{*}{$\begin{array}{c}\text { Month } \\
1954\end{array}$} & \multicolumn{4}{|c|}{ Rattus norvegicus } & \multicolumn{4}{|c|}{ Rattus rattus } & \multicolumn{3}{|c|}{ Total } \\
\hline & \multirow{2}{*}{ Host No. } & \multicolumn{3}{|r|}{ Mite } & \multirow{2}{*}{ Host No. } & \multicolumn{3}{|r|}{ Mite } & \multirow{2}{*}{$\begin{array}{l}\text { Host } \\
\text { No. }\end{array}$} & \multicolumn{2}{|c|}{ Mite } \\
\hline & & No.II & Mean & 1) Individual No. & & No.|I & Mean & Individual No. & & No. & Mean \\
\hline Aug. & 2 & 0 & 0 & & 2 & 0 & 0 & & 4 & 0 & 0 \\
\hline Sep. & 26 & 0 & 0 & & 5 & 0 & 0 & & 31 & 0 & 0 \\
\hline Oct. & 8 & 0 & 0 & & 1 & 0 & 0 & & 9 & 0 & 0 \\
\hline Nov. A & 10 & 18 & 1.8 & $18,0 \times 9$ & 1 & 0 & 0 & & 11 & 18 & 1.6 \\
\hline $\mathrm{B}$ & 8 & 35 & 4.4 & $26,3,3,3,0 \times 4$ & 2 & 2 & 1.0 & 2,0 & 10 & 37 & 3.7 \\
\hline $\mathrm{C}$ & 12 & 78 & 6.5 & $\begin{array}{l}23,20,14,13 \\
3,3,2,0 \times 5\end{array}$ & 3 & 19 & 6.3 & $11,8,0$ & 15 & 97 & 6.5 \\
\hline Dec. $A$ & 13 & 457 & 35.1 & $\begin{array}{l}124,105,80,78 \\
29,16,13,8 \\
3,1,0 \times 3\end{array}$ & 5 & 242 & 48.4 & $\begin{array}{l}105,97,35,5 \\
0\end{array}$ & 18 & 699 & 38.8 \\
\hline $\mathrm{BC}$ & 3 & 4161 & 138.7 & $262,124, \quad 30$ & 1 & 6 & 6.0 & 6 & 4 & 422 & 105.5 \\
\hline $\begin{array}{l}1955 \\
\text { Jan. }\end{array}$ & 2 & 103 & 51.5 & 55,48 & 4 & 673 & $768=$ & $108 \quad 10400$ & & & \\
\hline Feb. AB & 13 & 408 & 31.4 & $\begin{array}{l}136,92,68,36,32 \\
26,8,7,3, \quad 0 \times 4\end{array}$ & 2 & 0 & 100.0 & $\begin{array}{l}408,104,89, \\
72\end{array}$ & $\begin{array}{r}6 \\
15\end{array}$ & $\begin{array}{l}776 \\
408\end{array}$ & $\begin{array}{c}129.3 \\
27.3\end{array}$ \\
\hline C & 10 & 318 & 31.8 & $\begin{array}{l}74,63,46,43, \\
34,31,27,0 \times 3\end{array}$ & 2 & 36 & 13.0 & 15,21 & 12 & 354 & 29.5 \\
\hline Mar. $A B$ & 10 & 343 & 34.3 & $\mid \begin{array}{l}66,65,60,40,30 \\
32,31,13,6,0\end{array}$ & 5 & 53 & 10.6 & $38,15,0 \times 3$ & 15 & 396 & 26.5 \\
\hline Apr. A & 6 & 4. & 0.7 & $3,1,0 \times 4$ & 0 & & & & 6 & 4 & 0.7 \\
\hline $\mathrm{B}$ & 5 & 2 & 0.4 & $2, \quad 0 \times 4$ & 0 & & & & 5 & 2 & 0.4 \\
\hline$c$ & 6 & 0 & 0 & & 2 & 0 & 0 & & 8 & 0 & 0 \\
\hline May, $A B$ & 7 & 0 & 0 & & 2 & 0 & 0 & & 9 & 0 & 0 \\
\hline $\mathrm{C}$ & 5 & 2 & 0.4 & $2, \quad 0 \times 4$ & 0 & & & & 5 & 2 & 0.4 \\
\hline June & 6 & 0 & 0 & & 3 & 0 & 0 & & 9 & 0 & 0 \\
\hline July & 8 & 0 & 0 & & 0 & & & & 8 & 0 & 0 \\
\hline Aug. & 6 & 0 & 0 & & 2 & 0 & 0 & & 8 & 0 & 0 \\
\hline Sep. & 10 & 0 & 0 & & 2 & 0 & 0 & & 12 & 0 & 0 \\
\hline Oct. & $\begin{array}{r}9 \\
185\end{array}$ & 0 & 0 & & $\begin{array}{r}0 \\
44\end{array}$ & & & & $\begin{array}{r}9 \\
229\end{array}$ & $\left|\begin{array}{r}0 \\
3,215\end{array}\right|$ & 0 \\
\hline
\end{tabular}

註 1 . A \&上旬, B \&中旬, Cは下的。

註 2. Host No. は宿主数, Mite は恙虫数, その No. は総計数, Mean は 1 頭平均笴生数, Individual No、は鼠の個体ごをに寄生していた数で, $0 \times 4$ は 0 正寄生が 4 頭の意味である。 
(238)

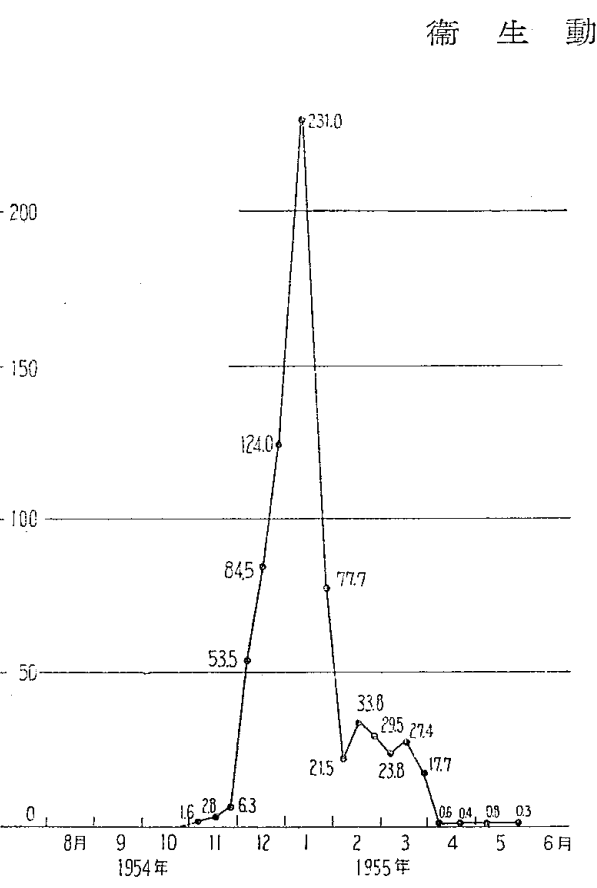

四 1 八丈島に揭りるタテッッガムシの季節消長 ドブ,クマネズミの旬別 1 頭平均寄生数. 1954 55(上野㿑治)

ここで注目すべきは林ら（1954）の報砧したように多デ

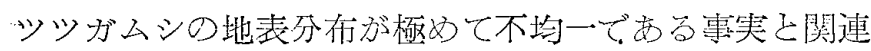

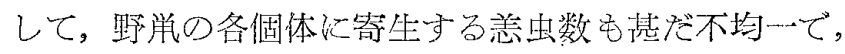

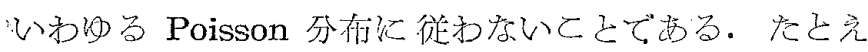
ば，1954年11月上旬《はドブネズミ10頭のう方1頭には 18正寄生していたが他の9頭には全く恙虫堂認めない し，最盛期の 12 月上旬に络ドブネズミ13頭の5 5124 疋

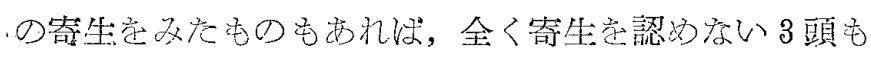

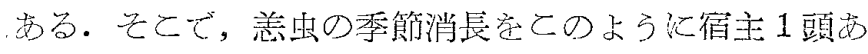

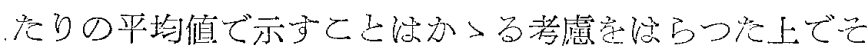

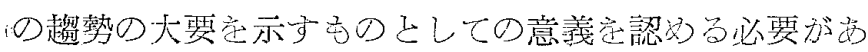
35.

本島比抬们五島型恙虫病の季節的登発生状況につい

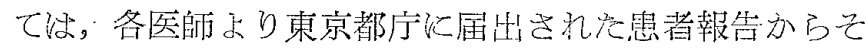

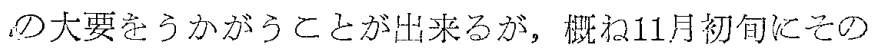

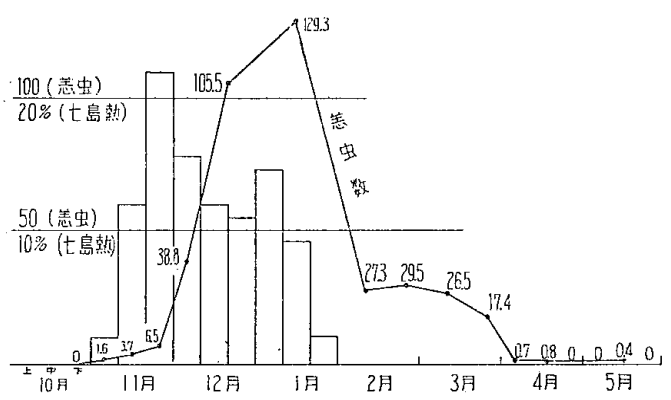

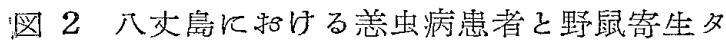
テッッガムシ数の月別消長（ドブ，クマ両 種の集計） 1954〜55，折線は宿主 1 頭あた りの恙虫数, タテ棒は患者の月別比率

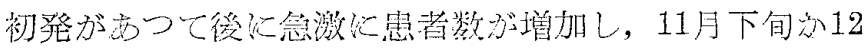

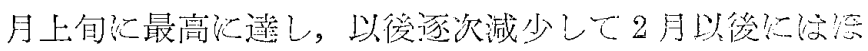

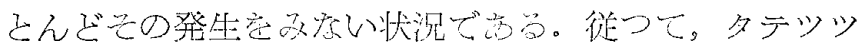

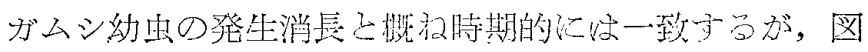

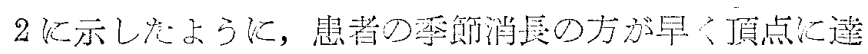

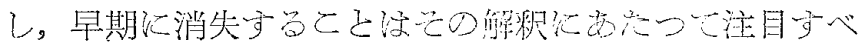

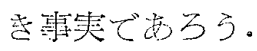

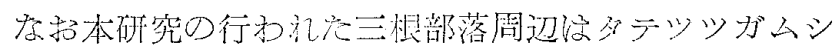
のみの繁殖地で，本種幼虫核人家の庭でしれUルドブネズ ミやクマネズミにさえも寄生して招り，乙の恙虫加いか に本島で普覓的化発生しているか应示している。しふ

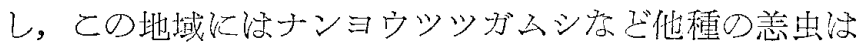
発生して招らず，乙れらの谷種の季節消長や生態に関し

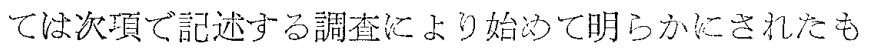
のである。

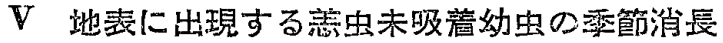

し〉でタテッッガムシの採集炕用いた心゙ークライト权 法さよぶものは鈴木ら（1953）の実施した方法に潐じ， 一辺 $1.5 \mathrm{~cm}$ 正方形の黒焦のベークライト板在 2 分間以上 地表に招き，乙の面に怡い上つた恙虫幼虫捕集してそ

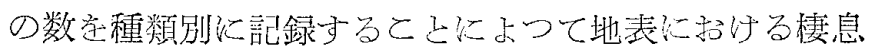
密度定推定するものである。この観察方法法こ虬加宿

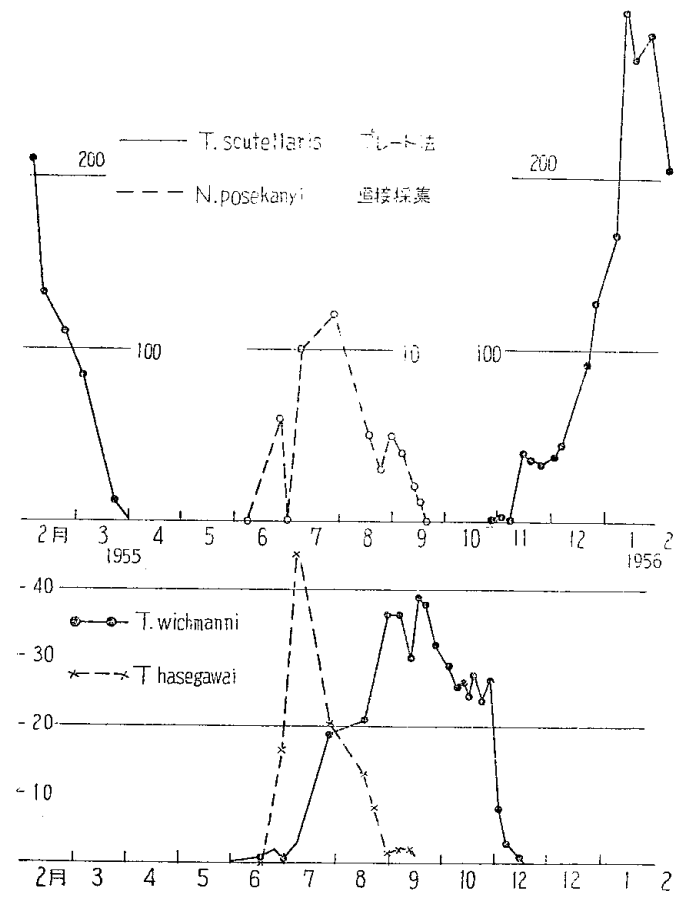

図 3 八大島の地表に饴ける各種恙出幼虫の 季節消長

主飞寄生しょうとしている恙虫幼虫学直接に地表から簡 単に証明しらるこいら点で劃期的な意義定むら，乙れ 㐘で地表分布密度の推定や恙虫の日週活動の研究なごに 


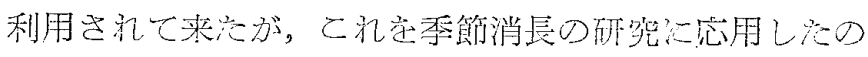

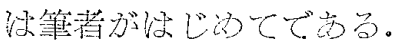

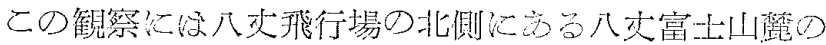

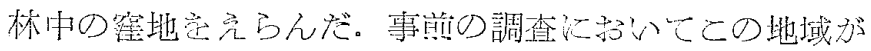

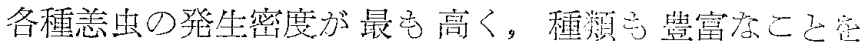

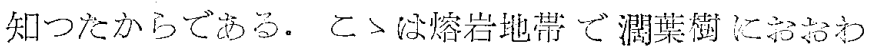

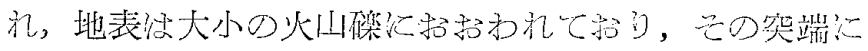

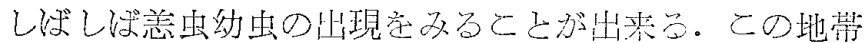

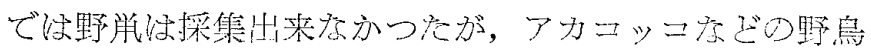

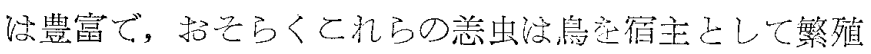

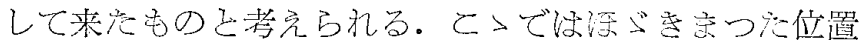
の地表炕心゙ークライト板赾延10回，备2 分間新いて採集 した幼出定すべてその場所でオ゙ム。クロラール栖本と

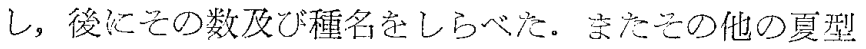
恙虫の幼虫の発生密度耑しらべるに心，特定の岩の上飞

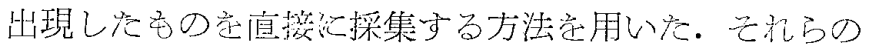
成績定日付順火表示すると表 4 而で図3のよう亿なる。

この地域で地表から見出された恙虫幼虫综タテッッガ ムシ，ナンヨウツツガムシ，入セガワッッガムシ，ポセ カニトリタマツツガムシ，バーンズツツガムシの5種と あこの3種がベークライト板上に结い上る性質が見出さ

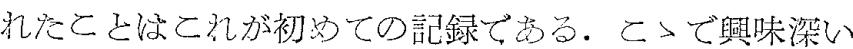
のはこの5種のうちタテッッガムシとバーンズッツガム シとが冬型で他の3 種は夏型の発生定示し，乙の両群が

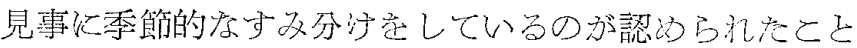
である。特化七島型恙虫病の媒介種上目されるタテッッ

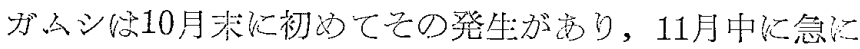
数定増して12月下旬少ら1月に方沙最高遠し，その後

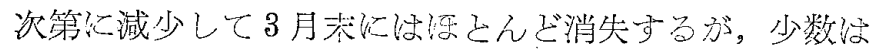

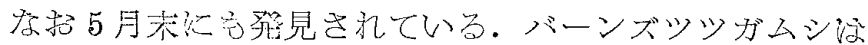
少数であつたが1月中にの多採集されている。乙㣗に反 して他の3種はタテッッガムシの全く消失した 6 月下旬

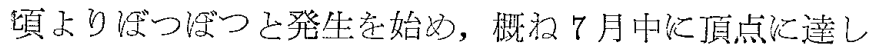
たが，ハセガワツツガムシとポセカニトリタマツツガム シは採集個体数も少く，発生期間む短くて9月中旬頃に 終息したのに反して，ナンヨウッツガムシは9月中はい

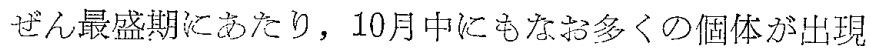
し，11月中旬悉で残存した。そしてタテッッガムシの発 生期こしぼらく重複してその出現がみられたが，気温の

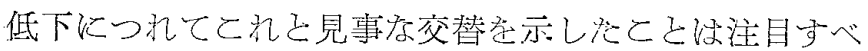
きである。

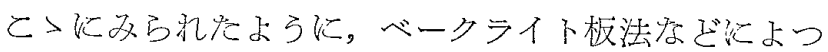

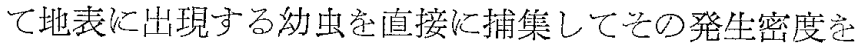
推定するこ己灿色从面办らの考察定必要亡する《せ よ, 従前から他の研筧者により試及られたよらな野巣な ごの宿主学捕えて間接にその消長学みる方法に比して誤

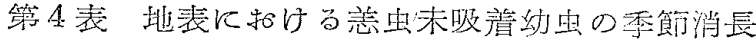
Seasonal distribution of larval trombiculid mites on the soil surface. Hachijo Island, 1954-56, by X. Ueno.

\begin{tabular}{|c|c|c|c|c|c|}
\hline Date & $\left|\begin{array}{c}T \\
\text { scutel } \\
\text {-laris }\end{array}\right|$ & $\begin{array}{c}T \\
\text { wich } \\
-m a n n i\end{array}$ & $\begin{array}{c}T \\
\text { hase- } \\
\text { gawai }\end{array}$ & $\begin{array}{c}\text { Neo. } \\
\text { pose } \\
\text {-kanyit }\end{array}$ & $\begin{array}{c}T \\
\text { burnsi }\end{array}$ \\
\hline \multicolumn{6}{|c|}{1955} \\
\hline Feb. & 211 & 0 & 0 & 0 & \\
\hline & 209 & 0 & 0 & 0 & 0 \\
\hline & 133 & 0 & 0 & 0 & 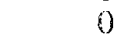 \\
\hline & 110 & 0 & 0 & 0 & 0 \\
\hline Mar. & 4 & 0 & 0 & 0 & 0 \\
\hline & 49 & 0 & 0 & 0 & 0 \\
\hline & 17 & 0 & 0 & 0 & 0 \\
\hline & 28 & 0 & 0 & 0 & 0 \\
\hline $\mathrm{Apr}$ & 4 & 0 & 0 & 0 & 0 \\
\hline & 11 & 0 & 0 & 0 & 0 \\
\hline & 25 & 0 & 0 & 0 & 0 \\
\hline May. & 2 & 0 & 0 & 0 & \\
\hline & 30 & 0 & 0 & 0 & 0 \\
\hline Jun. & 18 & 1 & 0 & 0 & 0 \\
\hline & $\begin{array}{l}25 \\
30\end{array}$ & $\begin{array}{l}2 \\
1\end{array}$ & $\begin{array}{r}8 \\
16\end{array}$ & 6 & 0 \\
\hline Jul. & 7 & 6 & 45 & 10 & 0 \\
\hline & 26 & 19 & 20 & 12 & 0 \\
\hline Aug. & 36 & 21 & 13 & 5 & 0 \\
\hline & 22 & 29 & 8 & 3 & 0 \\
\hline & 29 & 36 & 1 & 5 & 0 \\
\hline Sept. & 5 & 36 & 2 & 4 & 0 \\
\hline & 12 & 30 & 2 & 2 & 0 \\
\hline & 15 & 39 & 0 & 1 & 0 \\
\hline & 19 & 38 & 0 & 0 & 0 \\
\hline & 25 & 32 & 0 & 0 & 0 \\
\hline Oct. & 0 & 29 & 0 & 0 & 0 \\
\hline & 8 & 26 & 0 & 0 & 0 \\
\hline & 12 & 27 & 0 & 0 & 0 \\
\hline & 15 & 24 & 0 & 0 & 0 \\
\hline & 17 & 28 & 0 & 0 & 0 \\
\hline & 20 & 25 & 0 & 0 & 0 \\
\hline & 22 & 19 & 0 & 0 & 0 \\
\hline & 27 & 22 & 0 & 0 & 0 \\
\hline Nov. & 2 & 8 & 0 & 0 & 0 \\
\hline & 7 & 3 & 0 & 0 & 0 \\
\hline & 14 & 1 & 0 & 0 & 0 \\
\hline & 36 & 0 & 0 & 0 & 0 \\
\hline & 24 & 0 & 0 & 0 & 0 \\
\hline & 87 & 0 & 0 & 0 & 0 \\
\hline Dec. & 89 & 0 & 0 & 0 & 0 \\
\hline & 45 & 0 & 0 & 0 & 0 \\
\hline & 92 & 0 & 0 & 0 & 0 \\
\hline & 28 & 0 & 0 & 0 & 0 \\
\hline 1956 & & & & & \\
\hline Jan. & 167 & 0 & 0 & 0 & 1 \\
\hline & 298 & 0 & 0 & 0 & 2 \\
\hline & 270 & 0 & 0 & 0 & 2 \\
\hline & 285 & 0 & 0 & 0 & 2 \\
\hline eb. & 203 & 0 & 0 & 0 & 0 \\
\hline
\end{tabular}

差の要因が少いた放，季節消長の観察にあたつても変 動の少いスムースな曲線がえられたととは今後のこの分 野の研究に資する面が大きい己考光る。 


\section{VI 各種恙虫の疫学的考察}

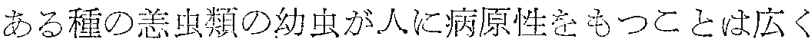
知られているとしるであるが，これ化惊 2 つの異つた作

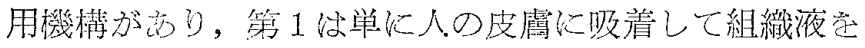

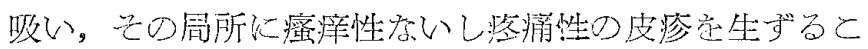
と，第 2 㤁このきい恙出病の病原りケッチアを感染さ 出て恙虫病离す起すととでする。八夫地方では，夏に ナンヨウツッガムシが発生して，その棲息地膟に立入る

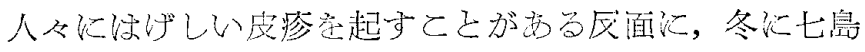

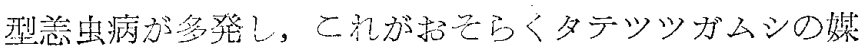
介に上るもので古るらと推定されている。しかし, 本種が

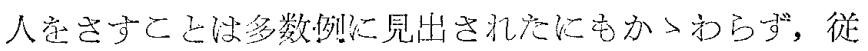
来の人体実駼例では未だ 1 例它奏際発病した者がない ので，未だ確証水到達していないと云わざるをえない。 その他の種類については，バーンズッッガムシが陮 1 回 人体に寄生していたをいう椠実が認力られたの文で，他

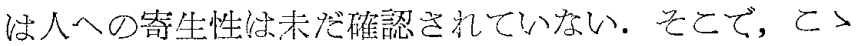
に注主さしてタテッツガムシの疫学的な考察学まさわて タることにしたい。

八灭島地方の十島型恙虫病の疫学的な報告としては雨 京都衛生局員方 3 回《わたり「七島熱の研究 I, II , II 」 に䛨述して招り，その比較㾤学飞ついて佐々（1955，

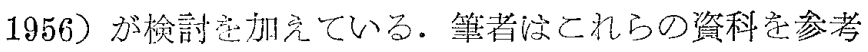
にし，自ら調查したタテッッガムシの生態及び七島熱患

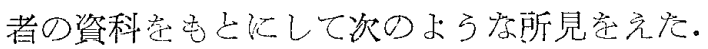

1. 発生の李節的関係 いわ河当七島蔡方冬型の発生

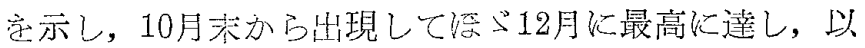

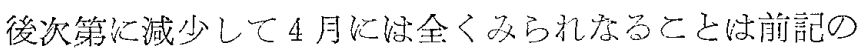
統計資科更び等者の治潦記録から多ても明らかで亦る。 むしてれが恙虫幼虫化小り感染するものとしたら，ナン ヨウッッガムシのような夏型種によるものでないとと姝 明らかで, 当地方の冬型, 即らタテッツガムシとバーン

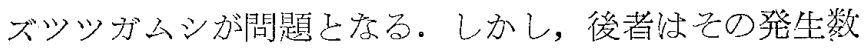
も甚だ少く，発生地す山狇の一部にの艮られている。

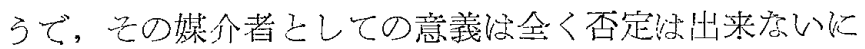
しても，多テッッガムシに比してほ可能性が低いものと 推定される。

しかしこ〉で興味深いこさ泳図 2 に示したようにタ テッツガ、シの発生曲線と，患者の発生曲線々飞完全な 平行はみられず，患者はタテッッガムシの発生初期に速 かに頂点に達し，その最盛期にほ既に衰退の傾向がみら 机る事奏で京る。この現象の解釈に注さらに慎重な検討 が加えら礼るべきであろう。

2. 地域分布 図 4 《1954年示ら55年に㚈筆者が三 根治いて診療した患者の住家学その発生の早いものか

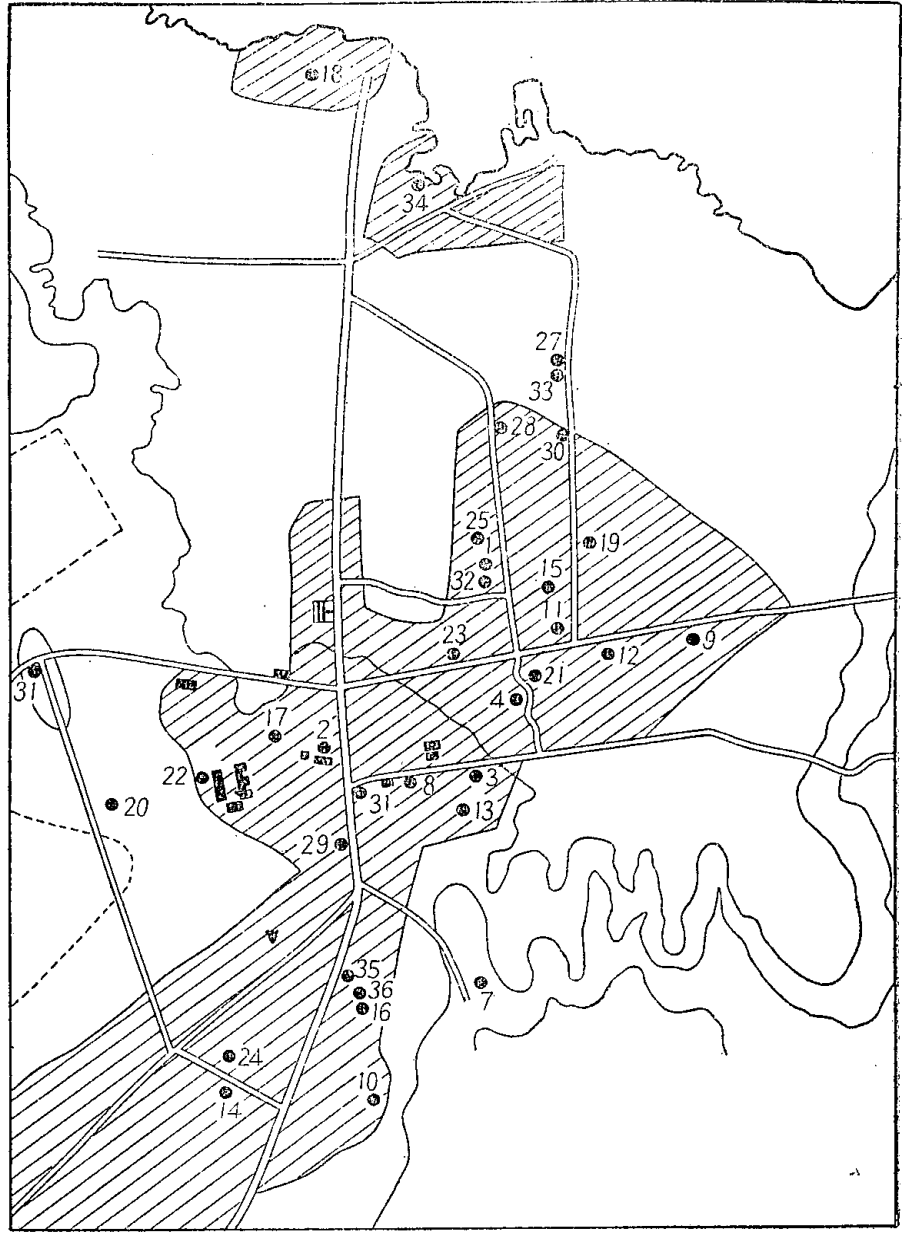

図4

八文島三根部落の恙虫病患者発生分布 (1954 55) 番号性患者の発生順を示す

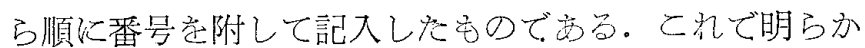
なととは，1号から36号密での患者の発生地に全く関逨 がなく，漹ぶ平等炕ての部落に散在しているととであ る. 即ち，乙の疾患快水系や食物飞小る感染で注なく，

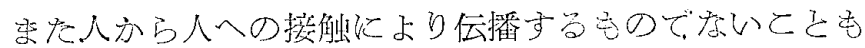
明らかで，乙の地带飞広沉に分布主当要因亦らの偶発的 な感染江まるもの之推定される。恙虫にとの原因学求好

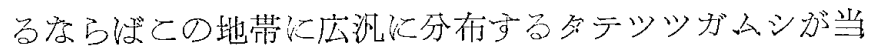
然已㣗侅当方。

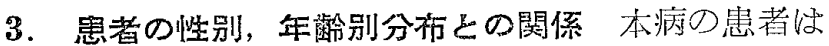
男女別の差が漂之んざなく，年踰的以は幼览，学童火多 数発生し，青壮年に比してもその罹患摔が高いことは本 州の新潟型恙虫病已全くその様相㓯飞する。八开島地

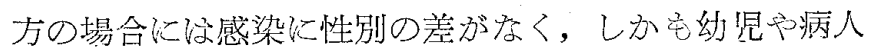

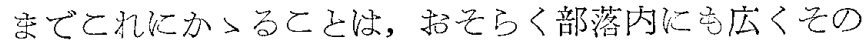

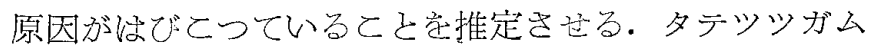
シ幼虫が山林や耕地の反ならず，人家の庭や小学校校庭 にさえも括びたざしく発生する事実は本病の疫学相によ く一致している.

4. タテッッガムシの人体寄生性 本種幼虫が人をさ 
すかどうかはようやく1952年にたしからられたこよで， それ以来筆者らも20例志りについて実際に人体加らこ の幼虫定摘出している。最す多い例では缥ざ全身にわた

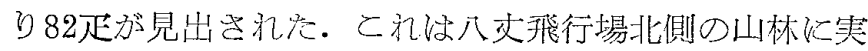

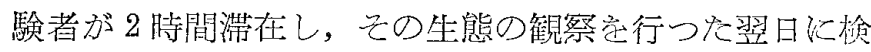

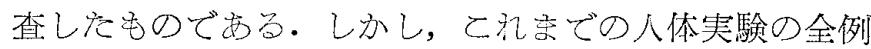

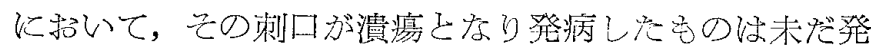

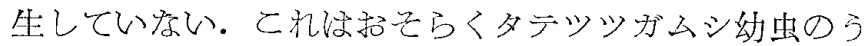
与, 奏際に病毒定保有しててれ考人に感染させる能力学 むつている個体が甚だ少いもの上仮定すれれ゙容易《説明 のつくことで，八丈島民の小う飞長期飞わたり多数の虫 にさ〉狆ている場合に经偶発的比感染が只られるむの上 考えている.

こ〉で興味深いととは，タテツツガムシ刺口部位の皮

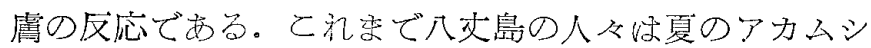
(ナンヨウッツガムシ) について活広くその存在定知つ

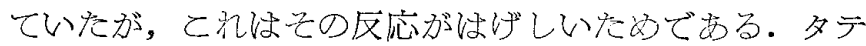

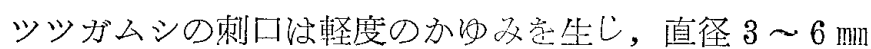

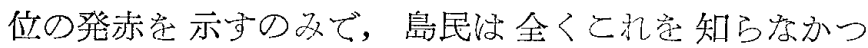

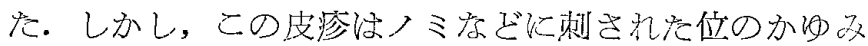

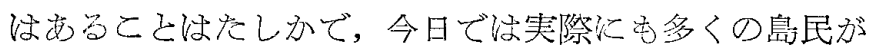
し犯定自覚するようになつている。

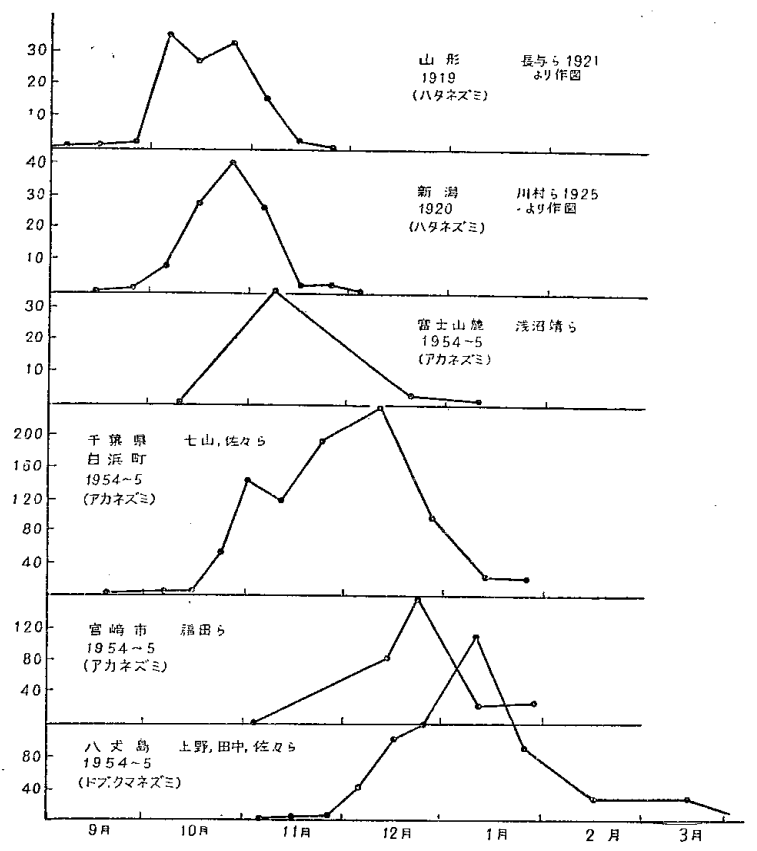

図 5 日本各地に指けるタテッッガムシの季節消辱 図（野鼠 1 頭わたり平均等生数の推移）

5. 他地方の七島型意虫病流行地との比較 本病浪伊 豆諸島注も己より，本州，九州の各地に散在して発生して いるここがたしかめられ，或就推定されているが，特に これらの各地域のタテッッガムシスび本病の季節発生に ずれのあるここが注目される。佐从らの集積した資科に
もとづいてての両者の季節発生曲線き示したのが図 5 及 び図6である。てれ㐫みると，タテッツガムシの幼虫の 発生注原則已して秋办ら冬に加ての季節であるが，南 方漂ごその発現が招它く，しふむ発生期間が長くて，等 者のしらべた八丈島のものが最も極端飞位している。七 島型恙虫病の季節分布が明らかなの活富士山簏，大島， 八文島の3カ所だけであるが，こ㣗を文ても近似の傾向 が漓り，タテッツガムシとの関連がこの点であ注目され k.

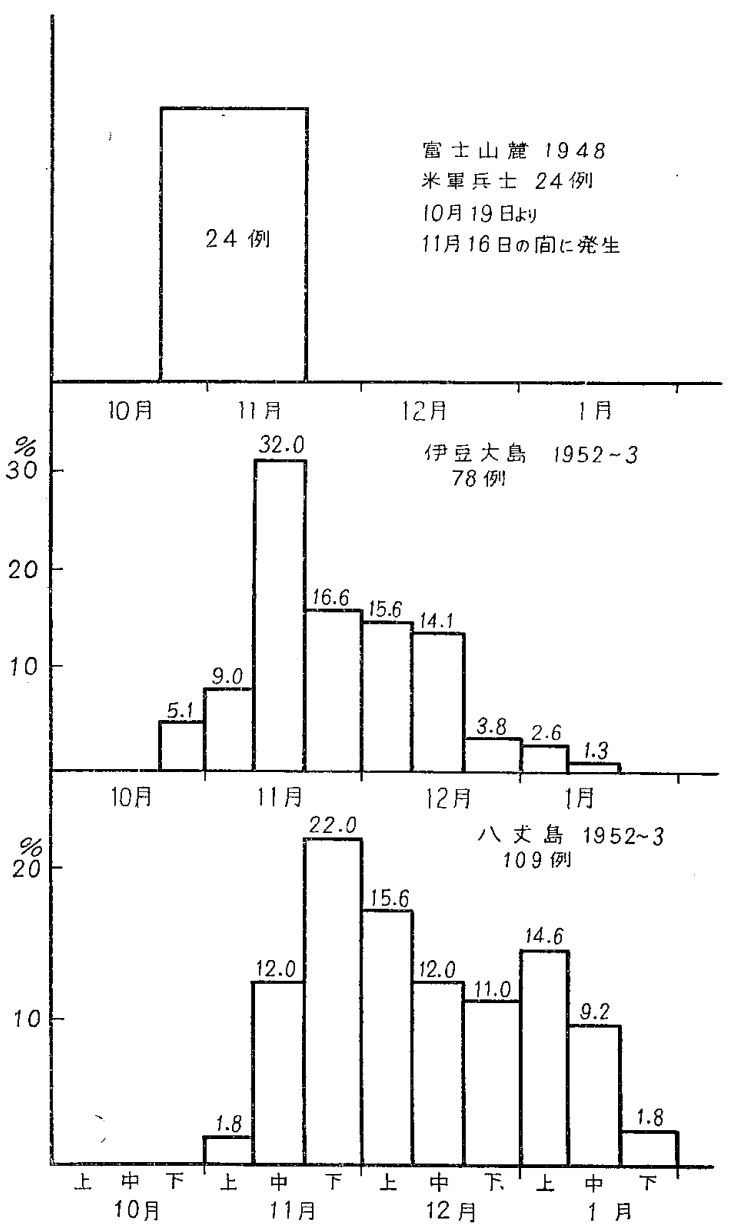

図 6 七島型恙虫病の季節発生比率 (旬別)

\section{VII むとあ}

1. 筆者は 伝研寄生虫研究部已共同で 1952 年から八 丈島地方の恙虫の生態及び疫学に関する研究走継続し, 当地方の恙虫相の特徵を明ら方にしたと共に，興味ある 新知見它た。

2. 八丈地方（八丈島，小島なざ）にこ记整で見出さ れ危恙虫性 Trombicula 属のタテッッガムシ，バーンズ ツツガムシ，タミヤツツガムシ，八セガワツツガムシ， ナンヨウツツガムシ及び Neoschöngastia 属(トリタマ ツツガムシ属）のポセカニ，ソロモン，カーバー，モン ティコラ，パエニテンスの計10種であつた。この中には 八セガワ，バーンズ，ナンヨウのよろな日本の他の地域 
に原こんど見出されない種類も方る反面に，本州はも己 ょり，同じ伊豆諸島の三宅島悹で豐富に見出さ礼るフ ジキタサト，ヤマトの小うな種頪が発見されていない

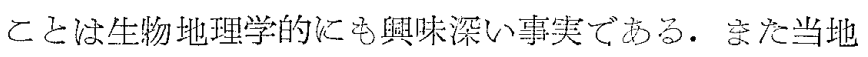
万には冬にタテッツガムシがこうてい他の地方に注見ら

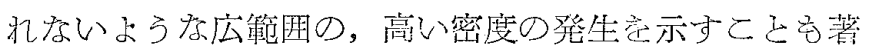
しい特徴であり，七島型恙虫病が大発生する事实々も関 連して疫学上興味深い。

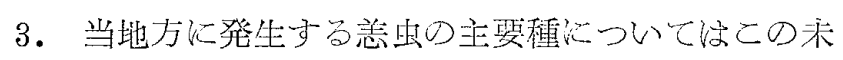

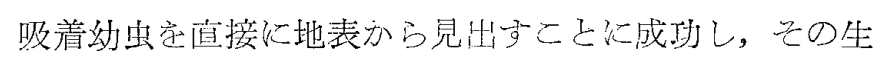
態について多くの新事実学見出した．タテッッガムシに ついては，人が近ずくとこれが地表の岩や小枝なよ゙の突 端行無数の集団をなして出現するこ己，これらが平時惊 乫端に近い吻かげに集落を形成して静止しているが，人， 鳥，愬などの宿主が近づくと主としてその呼気中の炭酸 ガスによつて刺战され，運動堂開始して突端にかけ登 り，宿主にふれる機会空つかむことが明らかにされた。

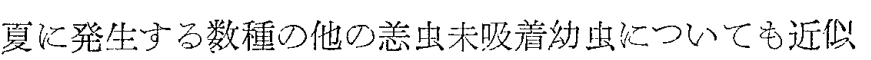
の，しかしや〉異つた反応定示す留性方古ることす認 わ，その宿主特異性の機構についても検討至加えた。

4.八丈島の野临岕本州及心゙三宅島末での伊豆諸島の 動物相己異つてハタネズミやアカネズミが見出されず， 専らドブネズミさクマネズミが棲息し，恙虫の重要な宿

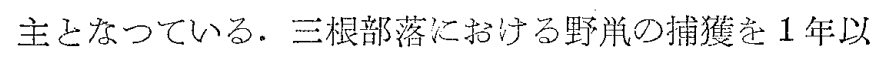
上にわたりつぶけててれ徛生する恙虫幼虫の季節消長 をしらべをとろ,タテッツガムシの1種だけが見出され,

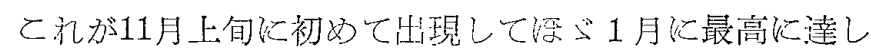
その後次第飞減少して5月ないし6月に全く消失与るて と妾知つた。これが本州の他の地力のタテッツガムシ幼

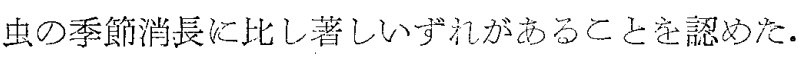

5. 八丈飛行場北側の山林で地表飞出現する恙虫幼虫

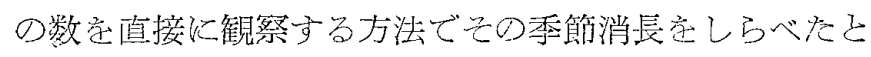
ころ,タテッッガムシは前項炕のべたような冬型の発生 定示すが，夏に洼てれと交代してナンヨウッッガムシ， 八セガワツツガムシ，襍セカニトリタマツツガムシの3 種が混合して発生し，てのうちナンヨウッツガムシは発 生期間㣻他の 2 種比して長いと己を見出した。

6. 当地方に見出さ㣙た10種の恙虫のうち, その疫学 的意義が注目さ犯るの㤝夏発生するナンヨウッツガム シが人に活げしい皮疹定生ずるこを，冬燈生するタテ ツツガムシが多くの人爪代寄生して軽度の癌㾕性の反忘

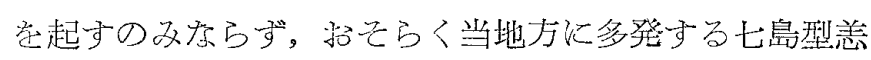
虫病竞媒介すると推定されることである。他の種類につ

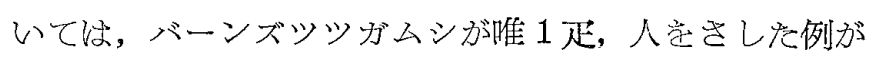

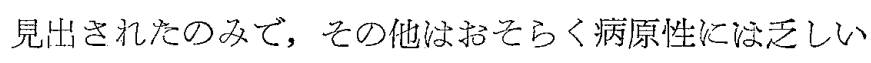
ふ，全くないものが多いさ考える。

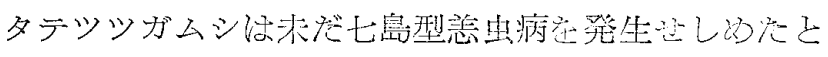

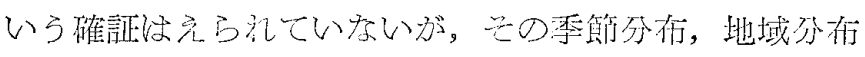

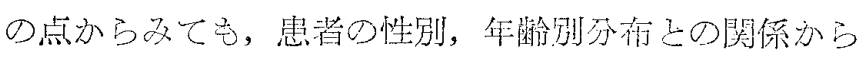

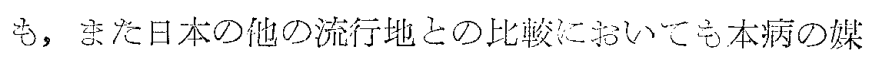
介者で市る可能性が強い。

\section{第 2 編 入文息の意䖵病の研究}

\section{I 研究経過}

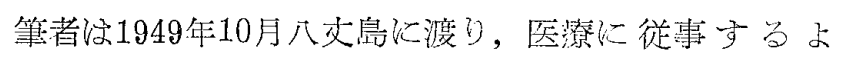
うになつて間もなく，今迄化経歌したしとのない散発性

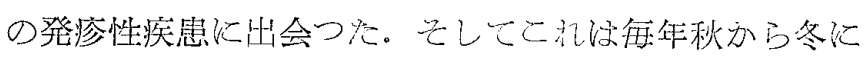
洂て流行する熱病で，島民間ではデング熱己呼んでい

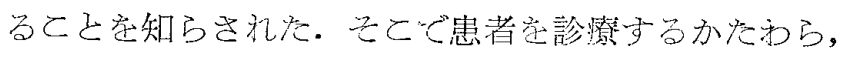
発疹性の熱性疾患に関する記載离さがしたこころ，1935 年飞北岡，山田雨氏が八丈島に招いて発疹熱さして記録

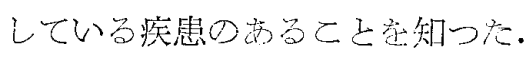

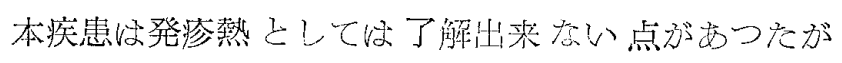
1950年度の流行期定宗つて熄試して为た。即占，モルモ ット定用いて Neill-Mooser 反応忧笑験しててたが全部 㓌性に終つた。1950年の流行期付本体をつかめないうち

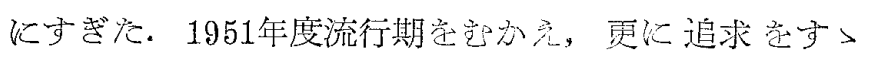
め, 患者堂観察していたところ, 偶然或る患者化恙虫病 にみるような测口発見した。そこで，他の患者定改め て見值すと何机の患者化むこ弘が見出され，己の後新し く発生する患者の殆んぞに刺口が見ら氿た．刺口の出来 る発疹性疾患已して证恙虫病方考完ら沉るが，当時いわ ゆ古典的恙虫病の概念しふなかつたたわ有疾患が恙 虫病の一型である己いうてと络考方られなかつた。古典

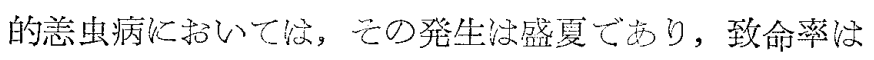

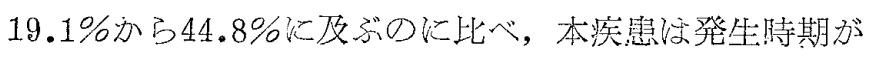
秋から冬にかけてであり，ての呚命率梳で零るからで ある。

当時, すでに佐从ら (1950) は八大島に冬型の恙虫の 発生するこ上美磪認して招り，この方面から八炎島のこ の風土病が冬型の恙虫病であること豪推定していた。 1951年12月飞宗京都, 伝研, 予研, 北里研究所等飞小方綜 合的な調查分行すれ, 本疾患方冬型の恙虫病で斿り, 伊 豆七島に分布するここが確認され，七島熱と仮称され そ。乙の型の恙虫病浮伊豆七島の他, 房総南部, 伊豆半 島, 富土山麓なごにも存在するここが知られ佐从(1955) はこ礼ら学七島型恙虫病とよんでいる。

本研究注筆者の診潦した本病患者について臨休所見の 系統的な研究起試反をすので, 徒前の島外研究者の観察 


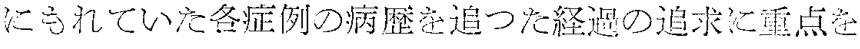
挡いをのである。

\section{II 一般症狀}

\section{1. 管 伏 期}

本症の潜伏期間定確实《判远しうる症例给稀でるる が，筆者の経唤した2例の䍐者炕ついて考察するる，12 日乃至13日己考充方肌るすがある。

第 1 例 40墄女, 1954年12月18日多刻胸部数力所, 虫

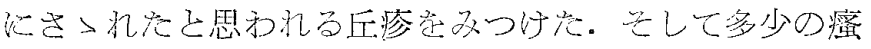

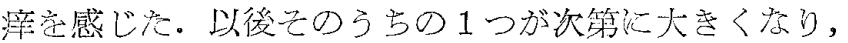
12月29日悪寒戦慄已共飞発症した㭙飞は小指影大の典型 的な刺口乞なつていた。找くの経験からする上恙虫に刺

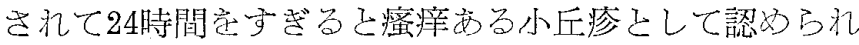

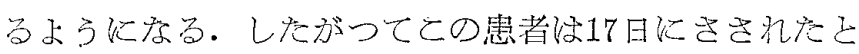
推定される。その日放えると13日目に発姃したしと 在る。

第 2 例 12歲男 1954年12月29日東京加来岛し， 31 日山に行つた。 そして 1 月11日惡寒戦慄己共心発症し

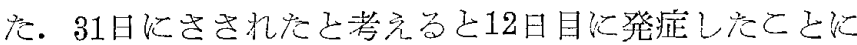
なる。な伃，伝研で钼察した例に10日〜14日の潠伏期さ 考光られる要のが尚。

\section{2. 前駆症 (表 1 )}

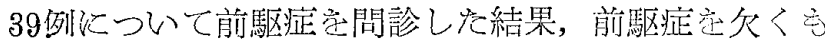
のが多く，次発病前日飞身体違和感意訴え弓亏の，感

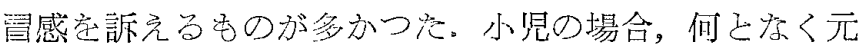
気がなかつたという場合が多い。しれは表では違和感の 中に入れた。(表 1)

\begin{tabular}{|c|c|c|c|c|c|}
\hline 前駆症 & 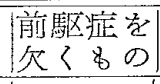 & 違和感 & 風邪感 & 頭 重 & $\begin{array}{l}\text { 淋巴腺 } \\
\text { 腄脹疼痛 }\end{array}$ \\
\hline 患者数 & 22 & 3 & 5 & 2 & 2 \\
\hline
\end{tabular}

\section{3. 制口（伎膚の初発病策）（表 2，図 1，2）}

恙虫病群に特有六症状の1つで，有對太恙虫幼虫にさ

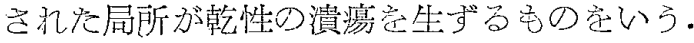

a. 刺口の部位（表2）.1952年度流行以降, 明方な 第 2 䒾 刺口の部位

\begin{tabular}{|c|c|c|c|c|c|}
\hline 胸 & 部 & 17 & 上 & 膊 & 3 \\
\hline 背 & 部 & 12 & 㓌 & 囊 & 3 \\
\hline 腋 裔 & 部 & 10 & 耳 & 蓂 & 2 \\
\hline 大 腿 & 部 & 7 & 前 & 膊 & 2 \\
\hline 腹 & 部 & 6 & 下 & 艆 & 2 \\
\hline 項 & 部 & 5 & 鼠 蹊 & 部 & 2 \\
\hline 頸 & 部 & 4 & 頭髮 & 部 & 1 \\
\hline 眼 & 瞼 & 3 & & & \\
\hline
\end{tabular}

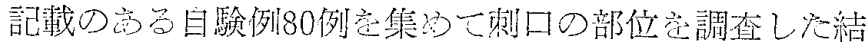

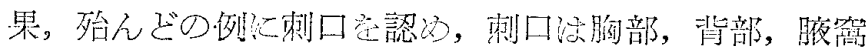

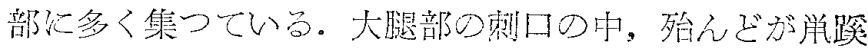

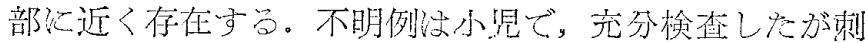

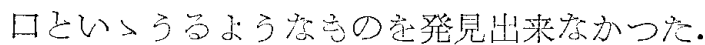

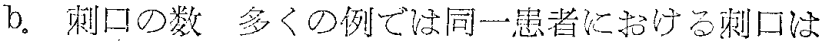

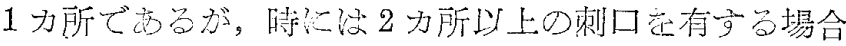

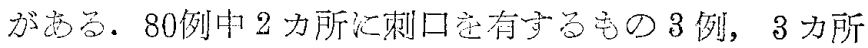

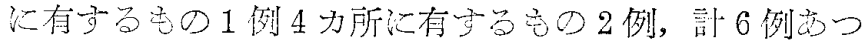

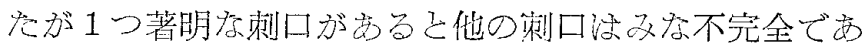
つた.

c. 刺口の樣相 刺口は大きなるの，小さ放无のさ多 様である。刺口の治愈に到る経過長短様々である。発

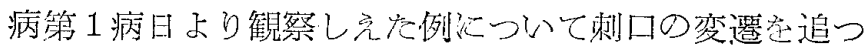
て名る上，

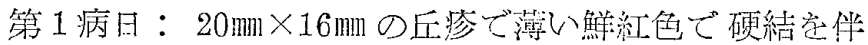

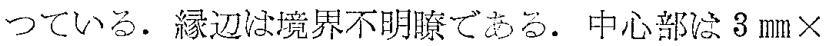
$3 \mathrm{~mm}$ 水泡がつぶれたようになつており，薄い表皮孛 透してその下惊や黄色がかつている。

第2病日：中心部はや>黑味がかつてくる.

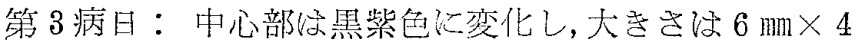

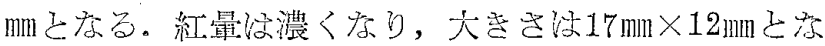
子.

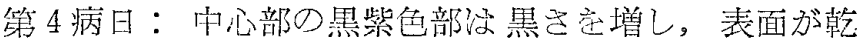

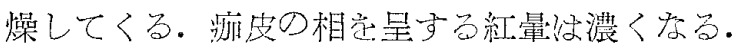

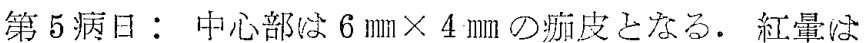

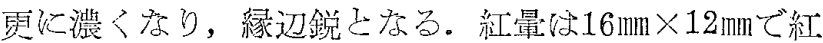
色の色調定增す。

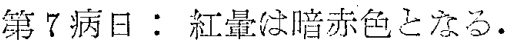

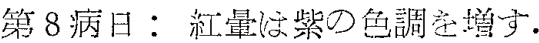

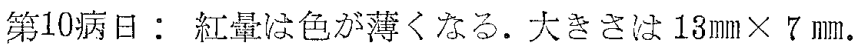
第12病日：紅量绝褐色上なり，雪炕薄くなり大きさ 9 $\mathrm{mm} \times 6 \mathrm{~mm}$. 版支注 $5 \mathrm{~mm} \times 4 \mathrm{~mm}$ ，周国飞約 $1 \mathrm{~mm}$ 巾落屑 字つけている。

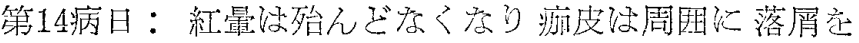

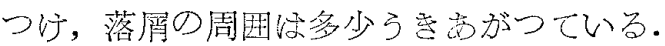

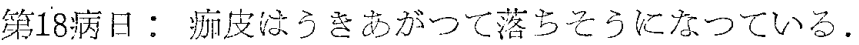

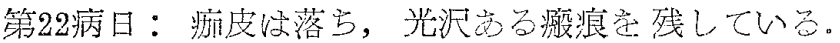

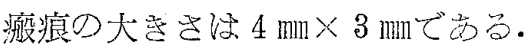

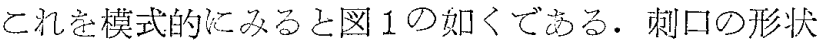

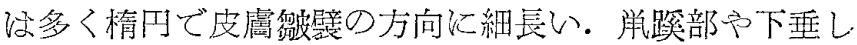

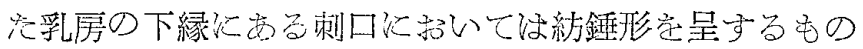
がある.刺口の大小症状の強弱飞比例与る場合が多い.

今，臨床症状の強弱孛 3 群火分け，発熱 $39^{\circ} \mathrm{C}$ 以上，発

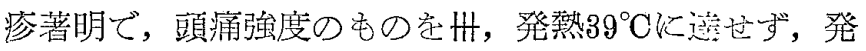
疹中等度，頭痛軽度のもの学H，発熱，発渗軽度で殆ん 


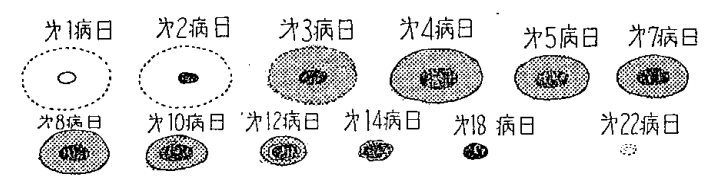

図 1 则口の病日による変化

註. 黒注泇皮, アミ目は発赤

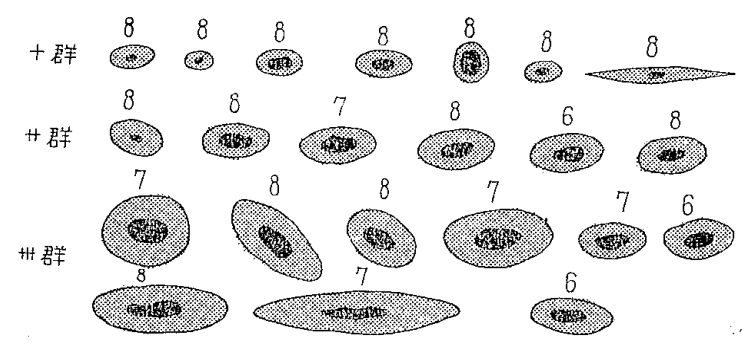

図 2 近接病日に於ける刺口の栐相,

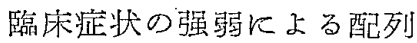

註. 刺口の上の数字は病日を表わす 黑は湤皮, アミ目は発赤

ぞ頭痛感さず，経過も短いものを十とし，各群について 接近した病日《拈当刺口の実物大模式図学配列してみ ると図 2 のようにな.

\section{4. 淋巴節の腫脹 (表 3 )}

初疹時《招いて殆えでの例に淋巴節の腫脹学認める。 この腫脹は卒病の全経過にわたつて初診時の大きさを持 繶する.特に刺口の所属する淋巴節は大きく腫脤し，圧 痛空訴える場合が多心．頭部，腋窩部，雀蹊部共，1侧 に1個であ大豆大以上に腫脹した淋巴節があればそれる

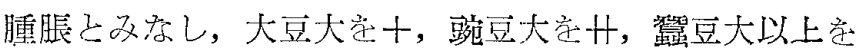

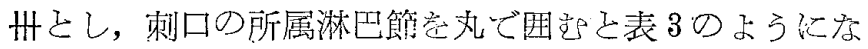
る.との表の中で，己゙しが所属淋巴節であるか不明なも の，即ち，刺口が背部，胸部などの正中線上にある場合

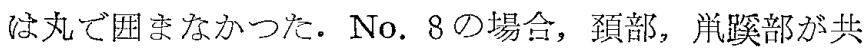
にサで，刺口の所属する淋巴節である腋窝部淋巴節が十 となつているの住，刺口に近い皮下淋巴節が超哣豆大に 腫脹し，压痛があるため上思われる。
定感した24例中，半数の12例炇戦溧を伴つた，頭痛，四

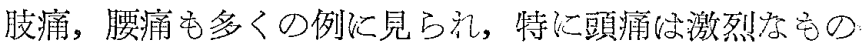
が女り，本病に括ける苦痛のいちね゙ん大きなものであ

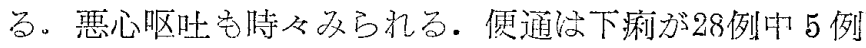

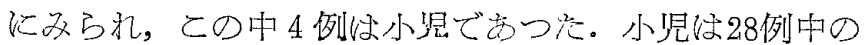
6 例であるが，この 6 例中 4 例は下疬安伴つた。便秘に 傾いたすの28例中 9 例，気管支炎合併したもの28例中

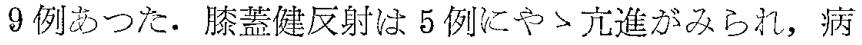

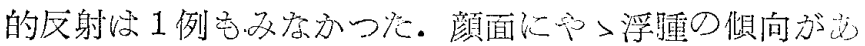

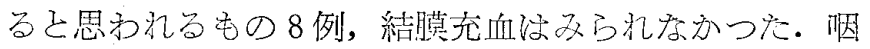

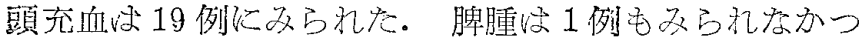

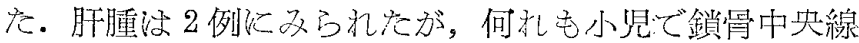
上に挍いて1.5棈指京㣗るの及であるから本病で肝腫

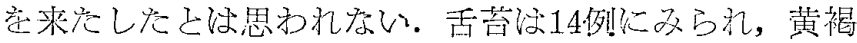

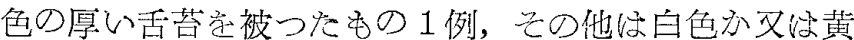

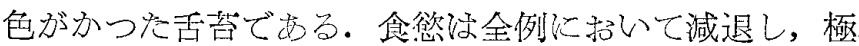
期には完全に食照消失した例も多い。自覚症状经第 7 病 日位後飞招讨る諸症状が本病の主たる安のである。こ> に記載与怠患者は2な7病日宋でに受診しているから受

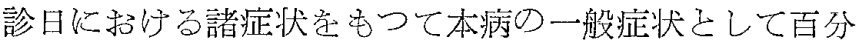

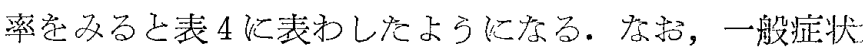
は幼少に軽く，成人に执いて重いようである。 第4表自 賞 症

\begin{tabular}{|c|c|c|c|c|c|}
\hline 症 & 状 & 百分率 & 症 & 状 & 百分率 \\
\hline 悪 & 寒 & $85 \%$ & 煫 & 濑 & $32 \%$ \\
\hline 戦 & 慄 & 43 & \multicolumn{2}{|c|}{ 膝蓋腱反射元進 } & 18 \\
\hline 発 & 熹 & 100 & 浮 & 腫 & 32 \\
\hline 頭 & 痛 & 82 & \multicolumn{2}{|c|}{ 胭頭充血 } & 64 \\
\hline 四 肢 & 痛 & 64 & 脾 & 腫 & 0 \\
\hline 腰 & 痛 & 64 & 肝 & 腫 & 0 \\
\hline 悪 & 心 & 18 & 腹 & 痛 & 11 \\
\hline 澏 & 吐 & 7 & 舌 & 苔 & 50 \\
\hline 下 & 㾥 & 18 & 食公 & 退 & 100 \\
\hline 便 & 秘 & 32 & 結 月 & 血 & 0 \\
\hline
\end{tabular}

第3 表 淋 巴 節 $の$ 脏 脹

\begin{tabular}{|c|c|c|c|c|c|c|c|c|c|c|c|c|c|c|c|c|c|c|c|c|c|c|c|c|c|c|c|c|}
\hline 虫者番号 & 1 & 2 & 3 & 4 & 5 & 6 & 7 & 8 & 9 & 10 & 11 & 12 & 13 & 14 & 15 & 16 & 17 & 18 & 19 & 20 & 21 & 22 & 23 & 24 & 25 & 26 & $27 \mid$ & \\
\hline $\begin{array}{lr}\text { 頸 } & \text { 部 } \\
\text { 腋 } & \text { 简 } \\
\text { 部 } \\
\text { 鼠 } & \text { 蹊 } \\
\text { 部 }\end{array}$ & 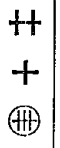 & $\begin{array}{l}+ \\
+ \\
+\end{array}$ & $\begin{array}{l}H \\
H \\
H\end{array}$ & $\begin{array}{l}t+ \\
(H H) \\
H+t\end{array}$ & $\begin{array}{l}+t \\
\text { (III) } \\
H\end{array}$ & $\begin{array}{l}H \\
\text { (Hii) } \\
+\end{array}$ & $\begin{array}{l}t+ \\
\text { (II) } \\
+t\end{array}$ & $\begin{array}{l}H \\
\oplus \\
H\end{array}$ & $\begin{array}{l}+ \\
- \\
\text { (II) }\end{array}$ & H+t & $\begin{array}{l}H \\
\text { (III) } \\
+\end{array}$ & $\begin{array}{c}+ \\
(H) \\
+\end{array}$ & $\mid \begin{array}{l}- \\
\oplus \\
-\end{array}$ & $\begin{array}{l}H \\
(H) \\
-\end{array}$ & $\begin{array}{l}- \\
\text { (iㅏ) } \\
-\end{array}$ & $\begin{array}{l}+ \\
(\boxplus) \\
+\end{array}$ & $\begin{array}{l}\boxplus \\
++ \\
-\end{array}$ & $\begin{array}{c}- \\
\text { (iii) } \\
-\end{array}$ & $\begin{array}{l}+ \\
\text { (P) } \\
+t\end{array}$ & $\begin{array}{l}+ \\
+ \\
\text { (II) }\end{array}$ & $\begin{array}{l}+ \\
(11 \\
+\end{array}$ & $\begin{array}{l}+ \\
(+11) \\
\mathrm{H}\end{array}$ & $\begin{array}{l}H \\
H \\
H\end{array}$ & (HB) & $\begin{array}{l}H+ \\
H \\
\text { (Hit) }\end{array}$ & $\begin{array}{l}H \\
\text { (車) } \\
H\end{array}$ & $\begin{array}{l}\text { 巴1 } \\
+ \\
+\end{array}$ & $\begin{array}{l}\mathrm{Ht} \\
\mathrm{Ht}\end{array}$ \\
\hline
\end{tabular}

\section{5. 自覚症狀（表 4)}

28例について自覚症学観察した結果，発熱㤬全例に久 られる必登の症状である。畏寒は28例中 24 例に夕られ， 悪寒学感じなかったもの3例，1例は幼少で不明．悪寒

\section{6. 熱型 (図 3)}

殆んご悪寒又は悪寒戦慄で発爇する。最初から高熱の もの，3〜4日の間に次第に上昇するもの，礉留するも の, 弛脤するものなざ様々である。熱の経過は10日から 


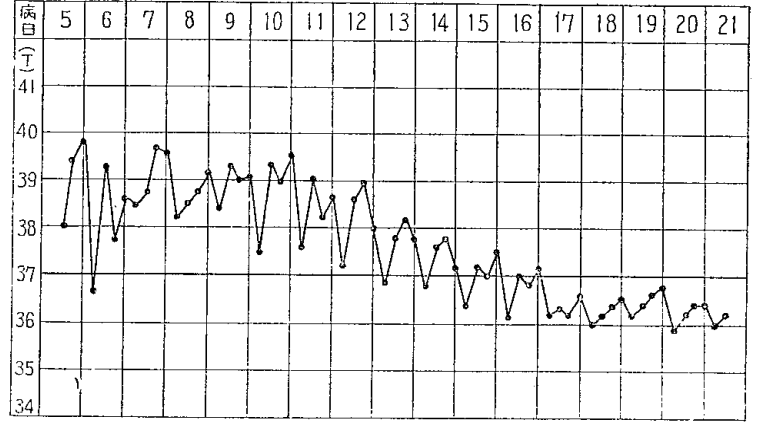

図 3 無处置の患者の筑型

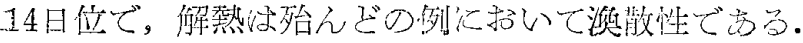

\section{7. 発疹 (表 5)}

全例飞久口れ行。好発部位经胸部，背部顔面，腹部で

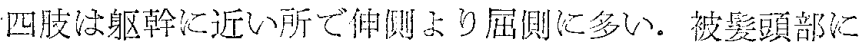

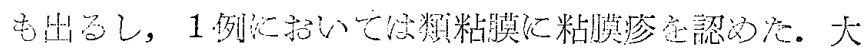

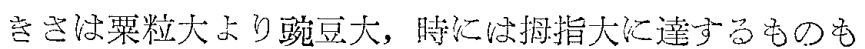
西る。数吱20〜30二位のものふら無数宗で種くの程度に

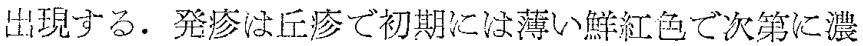
くなり，ついで暗赤色已なり，やがて褐色定括びて次第

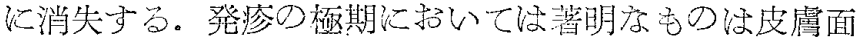

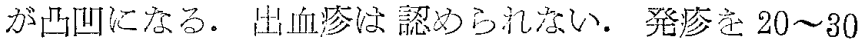

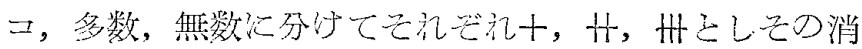

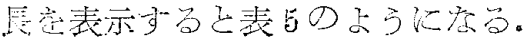

\section{III 臨床祫查成綪}

1. 血压(表6)

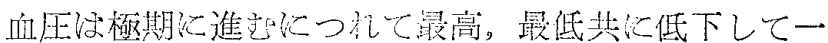

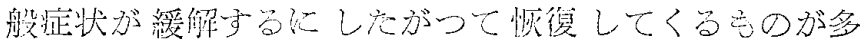
w.

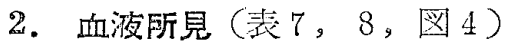

第 5 表病日飞よる発疹の推移

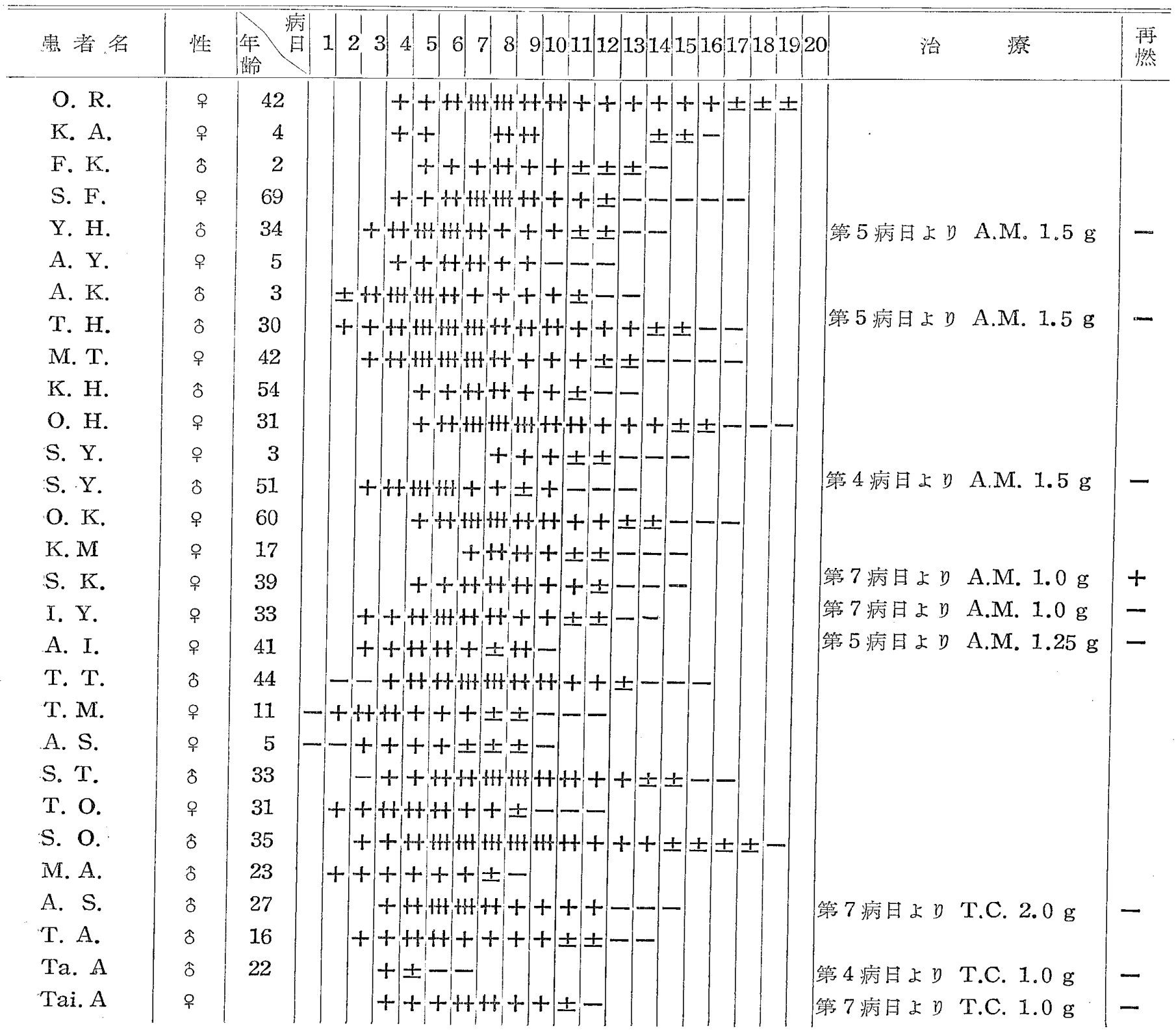


第6 表 血压の病日による推移 $(\mathrm{mmHg})$

\begin{tabular}{|c|c|c|c|c|c|}
\hline 患者名 & 性 & 年齢 & 病日 & 收縮期 & 拡張期 \\
\hline \multirow{3}{*}{ O. R. } & \multirow{3}{*}{ q } & \multirow{3}{*}{42} & 7 & 120 & 70 \\
\hline & & & 15 & 100 & 55 \\
\hline & & & 24 & 130 & 80 \\
\hline \multirow{7}{*}{ S. F. } & \multirow{7}{*}{ 우 } & \multirow{7}{*}{69} & 7 & 110 & 70 \\
\hline & & & 9 & 100 & 60 \\
\hline & & & 10 & 95 & 60 \\
\hline & & & 12 & 90 & 60 \\
\hline & & & 13 & 110 & 70 \\
\hline & & & 14 & 110 & 70 \\
\hline & & & 16 & 130 & 80 \\
\hline \multirow{2}{*}{ Y. H. } & \multirow{2}{*}{$\hat{\delta}$} & \multirow{2}{*}{34} & 6 & 120 & 60 \\
\hline & & & 8 & 130 & 60 \\
\hline \multirow{4}{*}{ T. $\mathrm{H}$. } & \multirow{4}{*}{$\hat{o}$} & \multirow{4}{*}{30} & 2 & 130 & 70 \\
\hline & & & 5 & 110 & 60 \\
\hline & & & 7 & 115 & 60 \\
\hline & & & 9 & 140 & 70 \\
\hline \multirow{2}{*}{ K. H. } & \multirow{2}{*}{$\hat{o}$} & \multirow{2}{*}{54} & 7 & 120 & 70 \\
\hline & & & 12 & 130 & 70 \\
\hline \multirow{3}{*}{ O. H. } & \multirow{3}{*}{ 우 } & \multirow{3}{*}{31} & 5 & 120 & 50 \\
\hline & & & 7 & 100 & 50 \\
\hline & & & 16 & 110 & 50 \\
\hline \multirow{2}{*}{ S. Y. } & \multirow{2}{*}{$\hat{\delta}$} & \multirow{2}{*}{51} & 3 & 140 & 70 \\
\hline & & & 7 & 110 & 60 \\
\hline \multirow{2}{*}{ S. K. } & \multirow{2}{*}{ 우 } & \multirow{2}{*}{39} & 7 & 120 & 60 \\
\hline & & & 10 & 140 & 70 \\
\hline \multirow{4}{*}{ T. T. } & \multirow{4}{*}{$\hat{8}$} & \multirow{4}{*}{44} & 2 & 125 & 70 \\
\hline & & & 7 & 110 & 50 \\
\hline & & & 8 & 115 & 50 \\
\hline & & & 10 & 120 & 50 \\
\hline
\end{tabular}

白血球数：14例の患者について経過宗追つて白血球 数字検查した結果，之の平均数怔第 1 病週に招いて減少 し，次第に恢復に向い，第 3 病週で正常に近くなる。

好中球：第1病週に捛いて，导でに55.5\%でその後

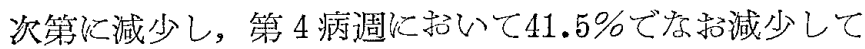

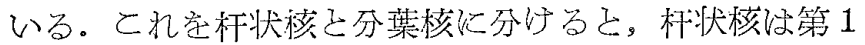

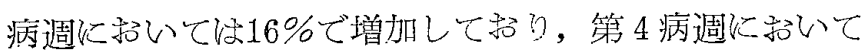

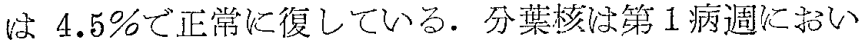

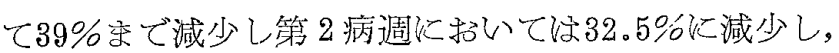

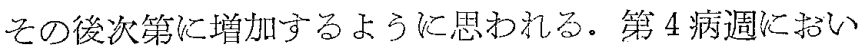
ても37\%で未だ恢復していない.リンパ球经增加する。 第1病週炕抬いて $42 \%$ ，その後 $49 \%$ が第 4 週案で続いて
第7表 七島熱患若白血球釉数

\begin{tabular}{|c|c|c|c|c|}
\hline 患 者名 & 性 & 年齢 & 病日 & 白血球総数 \\
\hline O. R. & $q$ & 42 & $\begin{array}{r}8 \\
15 \\
25\end{array}$ & $\begin{array}{l}5,000 \\
6,200 \\
5,000\end{array}$ \\
\hline K. A. & 우 & 4 & $\begin{array}{r}8 \\
16\end{array}$ & $\begin{array}{l}4,000 \\
8,800\end{array}$ \\
\hline F. K. & $\hat{o}$ & 2 & $\begin{array}{r}8 \\
22\end{array}$ & $\begin{array}{l}8,400 \\
9,000\end{array}$ \\
\hline S. F. & 우 & 69 & $\begin{array}{l}7 \\
9\end{array}$ & $\begin{array}{l}3,000 \\
5,300\end{array}$ \\
\hline Y. F. & $\hat{o}$ & 34 & $\begin{array}{r}5 \\
8 \\
14\end{array}$ & $\begin{array}{l}5,200 \\
6,200 \\
5,200\end{array}$ \\
\hline A. Y. & ㅇ & 5 & $\begin{array}{l}4 \\
9\end{array}$ & $\begin{array}{l}4,000 \\
9,200\end{array}$ \\
\hline A. $\mathrm{K}$. & $\hat{o}$ & 3 & 4 & 6,200 \\
\hline T. H. & $\hat{o}$ & 30 & $\begin{array}{r}2 \\
5 \\
7 \\
9 \\
14\end{array}$ & $\begin{array}{l}2,400 \\
2,400 \\
2,800 \\
4,000 \\
4,800\end{array}$ \\
\hline M. T. & P & 42 & $\begin{array}{r}3 \\
4 \\
8 \\
14\end{array}$ & $\begin{array}{l}5,200 \\
5,000 \\
3,800 \\
4,300\end{array}$ \\
\hline K. $\mathrm{H}$. & $\hat{\delta}$ & 54 & $\begin{array}{r}5 \\
7 \\
14\end{array}$ & $\begin{array}{l}3,600 \\
4,200 \\
5,600\end{array}$ \\
\hline O. H. & 우 & 31 & $\begin{array}{r}5 \\
7 \\
16\end{array}$ & $\begin{array}{l}3,600 \\
5,000 \\
6,200\end{array}$ \\
\hline S. Y. & $q$ & 3 & $\begin{array}{r}8 \\
16\end{array}$ & $\begin{array}{l}8,600 \\
7,800\end{array}$ \\
\hline S. K. & 우 & 41 & $\begin{array}{r}7 \\
10 \\
17 \\
26\end{array}$ & $\begin{array}{l}3,400 \\
3,600 \\
4,200 \\
5,000\end{array}$ \\
\hline I. Y. & 우 & 33 & $\begin{array}{r}7 \\
10 \\
14 \\
24\end{array}$ & $\begin{array}{l}3,200 \\
3,600 \\
4,000 \\
4,400\end{array}$ \\
\hline
\end{tabular}


第 8 姜 白血球百分率

\begin{tabular}{|c|c|c|c|c|c|c|c|c|c|c|c|}
\hline \multirow{2}{*}{ 患者名| } & \multirow{2}{*}{ 性| 年 } & \multirow{2}{*}{\multicolumn{2}{|c|}{ 朎 }} & \multirow[b]{2}{*}{ B. } & \multirow[b]{2}{*}{ E. } & \multicolumn{3}{|c|}{ N. } & \multirow[b]{2}{*}{ L. } & \multirow[b]{2}{*}{ Mon. } & \multirow{2}{*}{ Pl. } \\
\hline & & & & & & 計 & Seg. & St. & & & \\
\hline \multirow{4}{*}{ T.H. } & \multirow{4}{*}{ 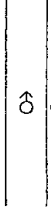 } & \multirow{4}{*}{30} & 2 & 0 & 0 & 68 & 40 & 28 & 31 & 1 & 0 \\
\hline & & & 5 & 0 & 2 & 66 & 30 & 36 & 29 & 3 & 0 \\
\hline & & & 15 & 0 & 3 & 52 & 35 & 17 & 41 & 2 & 2 \\
\hline & & & 28 & 0 & 5 & 45 & 39 & 6 & 47 & 3 & 0 \\
\hline \multirow{4}{*}{ O.F. } & \multirow{4}{*}{ 우 } & \multirow{4}{*}{4} & 3 & 0 & 0 & 53 & 44 & 9 & 46 & 1 & 0 \\
\hline & & & 7 & 0 & 2 & 49 & 36 & 13 & 47 & 3 & 1 \\
\hline & & & 14 & 0 & 4 & 40 & 34 & 6 & 51 & 3 & 2 \\
\hline & & & 28 & 0 & 3 & 32 & 29 & 3 & 60 & 4 & 1 \\
\hline \multirow{4}{*}{ O.R. } & \multirow{4}{*}{ 우 } & \multirow{4}{*}{42} & 4 & 0 & 0 & 51 & 44 & 7 & 47 & 2 & 0 \\
\hline & & & 8 & 0 & 1 & 48 & 34 & 14 & 45 & 4 & 2 \\
\hline & & & 15 & 0 & 3 & 42 & 33 & 9 & 51 & 4 & 0 \\
\hline & & & 23 & 0 & 5 & 32 & 28 & 4 & 57 & 6 & 0 \\
\hline \multirow{4}{*}{ A.Y. } & \multirow{4}{*}{ 우 } & \multirow{4}{*}{5} & 4 & 0 & 0 & 34 & 28 & 6 & 65 & 1 & 0 \\
\hline & & & 9 & 0 & 2 & 40 & 25 & 15 & 55 & 3 & 0 \\
\hline & & & 16 & 0 & 2 & 38 & 31 & 7 & 56 & 2 & 2 \\
\hline & & & 27 & 0 & 4 & 34 & 30 & 4 & 57 & 4 & 1 \\
\hline \multirow{4}{*}{ F.K. } & \multirow{4}{*}{$\hat{o}$} & & 4 & 0 & 0 & 54 & 49 & 5 & 44 & 2 & 0 \\
\hline & & 2 & 8 & 0 & 2 & 48 & 40 & 8 & 48 & 2 & 0 \\
\hline & & 2 & 17 & 0 & 0 & 34 & 28 & 6 & 64 & 2 & 0 \\
\hline & & & 22 & 0 & 4 & 36 & 30 & 6 & 56 & 4 & 0 \\
\hline & & & 5 & 0 & 1 & 51 & 35 & 16 & 46 & 2 & 0 \\
\hline & & 127 & 10 & 0 & 3 & 42 & 21 & 21 & 51 & 2 & 2 \\
\hline 11. & & & 16 & 0 & 2 & 39 & 30 & 9 & 58 & 1 & 0 \\
\hline & & & 26 & 0 & 4 & 41 & 37 & 4 & 52 & 3 & 0 \\
\hline & & & 5 & 0 & 0 & 52 & 37 & 15 & 46 & 2 & 0 \\
\hline & $\uparrow$ & 301 & 11 & 0 & 3 & 49 & 40 & 9 & 42 & 4 & 2 \\
\hline I. & 0 & 41 & 18 & 0 & 4 & 56 & 52 & 4 & 36 & 3 & 1 \\
\hline & & & 25 & 0 & 4 & 59 & 56 & 3 & 33 & 4 & 0 \\
\hline & & & 2 & 0 & 0 & 57 & 32 & 25 & 38 & 4 & 1 \\
\hline & $1 \%$ & & 5 & 0 & 0 & 49 & 39 & 10 & 48 & 3 & 0 \\
\hline $1 . \Pi$ & 0 & 34 & 14 & 0 & 3 & 54 & 45 & 9 & 38 & 4 & 1 \\
\hline & & & 27 & 0 & 4 & 62 & 58 & 4 & 24 & 5 & 0 \\
\hline K.A. & 우 & 14 & 8 & 0 & 0 & 39 & 36 & 3 & 59 & 2 & 0 \\
\hline S. Y. & $\hat{0}$ & 51 & 6 & 0 & 2 & 59 & 29 & 30 & 36 & 3 & 0 \\
\hline K. S. & 우 & 2 & 8 & 0 & 2 & 59 & 39 & 20 & 35 & 3 & 1 \\
\hline A.K. & 우 & 4 & 4 & 0 & 0 & 72 & 64 & 8 & 26 & 2 & 0 \\
\hline A.S. & क & 5 & 7 & 0 & 0 & 36 & 22 & 14 & 60 & 3 & 1 \\
\hline I. Y. & 우 & 33 & 23 & 0 & 4 & 33 & 26 & 7 & 57 & 4 & 2 \\
\hline
\end{tabular}

いる. 好酸球恃第 1 病週では殆んご消失している。その 出現沙第 7 病日頃である。単核球以全経過学通じ漂ざ正 常である・プラスマ細胞は全経過定通じ1〜2\%の出現

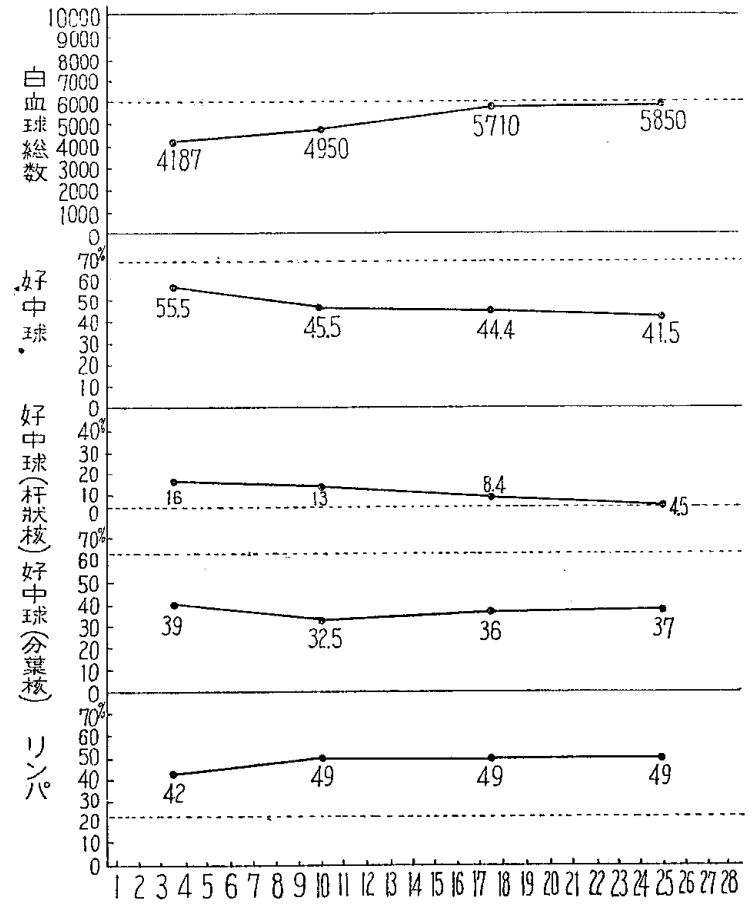

図 4 白血球像の病日に上る推移（平均值） 学忩た。

\section{Weil-Felix 友応（表9，図 5)}

Weil-Felix反応学22例について検查した結果，OXK に高度に凝集し，第 1 病週以内の平均值75倍に達し，第 4 病週の平均值は940 倍にも達した。 OX 2 Kついて 実施したが，使用抗元に疑間の点が生じたので，ての成 續住さらに検討の弓え報告するしことしたい.

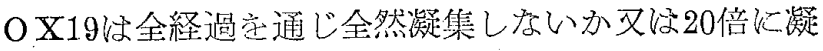

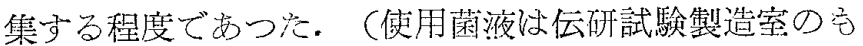
ので，製造潘号 OXK，OX19は No. 4, OX 2 は No. 3 , 菌株位㐾株)

\section{4. 肝 機 能}

a. 尿 Urobilinogen (表10) 患者17例について延40 回検查した結果，10例 (58.8\%) の患者性経過中陽性字

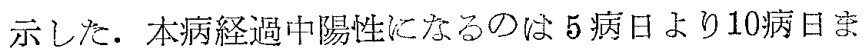
でで陰性化は比較的速い。

b.Thymol 混濁試験（表11）18例の患者について検 査した結果，5単位以上のすのが12例 $(66.6 \%)$ 飞及ら

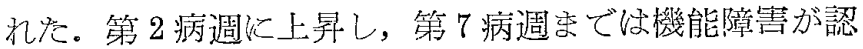
方方视。

c. Thymol 缺狀試験（表12）18例の惠者について検 查し流結果，11列 (61.1\%) 致病的で，第1病週《行つ

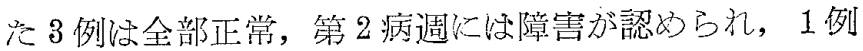

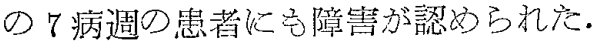

d. Kunkel E砝酸亞鉛試験（表 13）18例中 10 例

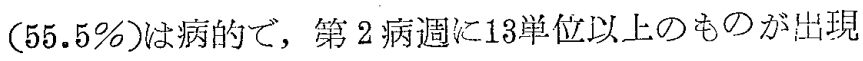
し，第 6 病週音では続くものがあつた。 
第 9 表 Weil-Felix 反応の推移

(一)は1:20(一)を示す

\begin{tabular}{|c|c|c|c|c|c|}
\hline 患 者名 & 性 & 年稌 & 病日 & OXK & OX 19 \\
\hline O. R. & 우 & 42 & $\begin{array}{l}14 \\
23 \\
29\end{array}$ & $\begin{array}{r}320 \\
1280 \\
1280\end{array}$ & $\begin{array}{l}20 \\
20 \\
20\end{array}$ \\
\hline K. A. & 우 & 4 & $\begin{array}{r}8 \\
16 \\
27\end{array}$ & $\begin{array}{r}80 \\
640 \\
1280\end{array}$ & $\begin{array}{l}(-) \\
(-) \\
(-)\end{array}$ \\
\hline F. K. & $\hat{\beta}$ & 2 & $\begin{array}{r}8 \\
22 \\
29\end{array}$ & $\begin{array}{r}80 \\
160 \\
160\end{array}$ & $\begin{array}{l}20 \\
20 \\
20\end{array}$ \\
\hline S. F. & $q$ & 69 & $\begin{array}{r}7 \\
12 \\
19 \\
29\end{array}$ & $\begin{array}{r}80 \\
160 \\
640 \\
1280\end{array}$ & $\begin{array}{l}(-) \\
(-) \\
(-) \\
(-)\end{array}$ \\
\hline Y. H. & 今 & 34 & $\begin{array}{r}5 \\
13 \\
22\end{array}$ & $\begin{array}{r}80 \\
80 \\
320\end{array}$ & $\begin{array}{l}(-) \\
(-) \\
(-)\end{array}$ \\
\hline A. Y. & 우 & 5 & $\begin{array}{r}4 \\
19 \\
30\end{array}$ & $\begin{array}{r}20 \\
640 \\
1280\end{array}$ & $\begin{array}{l}(-) \\
(-) \\
(-)\end{array}$ \\
\hline A. $\mathrm{K}$. & 令 & 3 & $\begin{array}{r}4 \\
10\end{array}$ & $\begin{array}{r}80 \\
1280\end{array}$ & $\begin{array}{l}(-) \\
(-)\end{array}$ \\
\hline T. H. & $\hat{\phi}$ & 30 & $\begin{array}{r}5 \\
9 \\
14\end{array}$ & $\begin{array}{l}20 \\
20 \\
80\end{array}$ & $\begin{array}{l}(-) \\
(-) \\
(-)\end{array}$ \\
\hline M. T. & 우 & 42 & $\begin{array}{r}4 \\
14 \\
20\end{array}$ & $\begin{array}{r}30 \\
320 \\
1280\end{array}$ & $\begin{array}{l}(-) \\
(-) \\
(-)\end{array}$ \\
\hline K. H. & $\hat{o}$ & 54 & $\begin{array}{r}7 \\
13 \\
19\end{array}$ & $\begin{array}{r}40 \\
160 \\
320\end{array}$ & $\begin{array}{l}(-) \\
(-) \\
(-)\end{array}$ \\
\hline O. H. & ㅇ & 31 & $\begin{array}{r}5 \\
7 \\
14\end{array}$ & $\begin{array}{r}80 \\
160 \\
640\end{array}$ & $\begin{array}{l}(-) \\
(-) \\
(-)\end{array}$ \\
\hline S. Y. & 웅 & 3 & $\begin{array}{r}8 \\
16\end{array}$ & $\begin{array}{l}320 \\
640\end{array}$ & $\begin{array}{l}(-) \\
(-)\end{array}$ \\
\hline
\end{tabular}

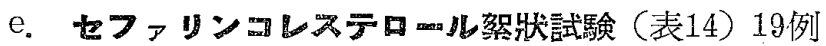
の患者中病的なものが 8 例 $(42.1 \%)$ あつ\%. そしてて れらの患者の経過飞対与る推移烛第 2 病週火上昇し，第 6 病週以降等正常火復するよう飞思われる。
第9表（つぶき）

\begin{tabular}{|c|c|c|c|c|c|}
\hline 患 者名 & 㤬 & 年齢 & 病日 & OXK & OX 19 \\
\hline S. Y. & 占 & 51 & $\begin{array}{r}5 \\
14\end{array}$ & $\begin{array}{r}80 \\
320\end{array}$ & $\begin{array}{l}(-) \\
(-)\end{array}$ \\
\hline O. K. & 우 & 60 & $\begin{array}{r}8 \\
14 \\
21 \\
28\end{array}$ & $\begin{array}{r}80 \\
160 \\
320 \\
640\end{array}$ & $\begin{array}{l}(-) \\
(-) \\
(-) \\
(-)\end{array}$ \\
\hline K. M. & 우 & 17 & $\begin{array}{r}7 \\
11 \\
19\end{array}$ & $\begin{array}{r}80 \\
160 \\
320\end{array}$ & $\begin{array}{l}(-) \\
(-) \\
(-)\end{array}$ \\
\hline S. K. & 우 & 39 & $\begin{array}{r}7 \\
10 \\
17 \\
26\end{array}$ & $\begin{array}{r}80 \\
160 \\
320 \\
1280\end{array}$ & $\begin{array}{l}(-) \\
(-) \\
(-) \\
(-)\end{array}$ \\
\hline I. $\mathrm{X}$. & 우 & 33 & $\begin{array}{r}6 \\
13 \\
23\end{array}$ & $\begin{array}{r}160 \\
320 \\
1280\end{array}$ & $\begin{array}{l}(-) \\
(-) \\
(-)\end{array}$ \\
\hline A. I. & 우 & 41 & $\begin{array}{r}3 \\
10 \\
18 \\
30\end{array}$ & $\begin{array}{r}40 \\
80 \\
160 \\
1280\end{array}$ & $\begin{array}{l}(-) \\
(-) \\
(-) \\
(-)\end{array}$ \\
\hline T. T. & $\hat{o}$ & 44 & $\begin{array}{r}2 \\
5 \\
8 \\
11 \\
20\end{array}$ & $\begin{array}{r}20 \\
40 \\
160 \\
640 \\
1280\end{array}$ & $\begin{array}{l}20 \\
(-) \\
(-) \\
(-) \\
(-)\end{array}$ \\
\hline T. M. & 우 & 11. & $\begin{array}{r}7 \\
18\end{array}$ & $\begin{array}{l}160 \\
320\end{array}$ & $\begin{array}{l}(-) \\
(-)\end{array}$ \\
\hline A. S. & 우 & 5 & $\begin{array}{r}3 \\
10 \\
21 \\
33\end{array}$ & $\begin{array}{r}40 \\
80 \\
160 \\
320\end{array}$ & $\begin{array}{l}(-) \\
(-) \\
(-) \\
(-)\end{array}$ \\
\hline S. T. & $\hat{\delta}$ & 33 & $\begin{array}{r}3 \\
15 \\
25\end{array}$ & $\begin{array}{r}80 \\
640 \\
1280\end{array}$ & $\begin{array}{l}(-) \\
(-) \\
(-)\end{array}$ \\
\hline
\end{tabular}

5.77日4

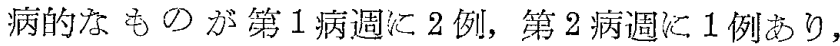
そ礼ぞれ10\% (45分), 15\% (30分) 及心゙40\% (30分) で 正常の 4 例住 2 病週 1 例 $5 \%$ (30分)，5病週 1 例 $5 \%$

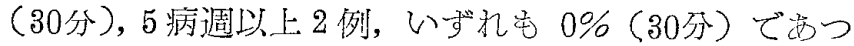

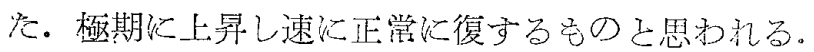




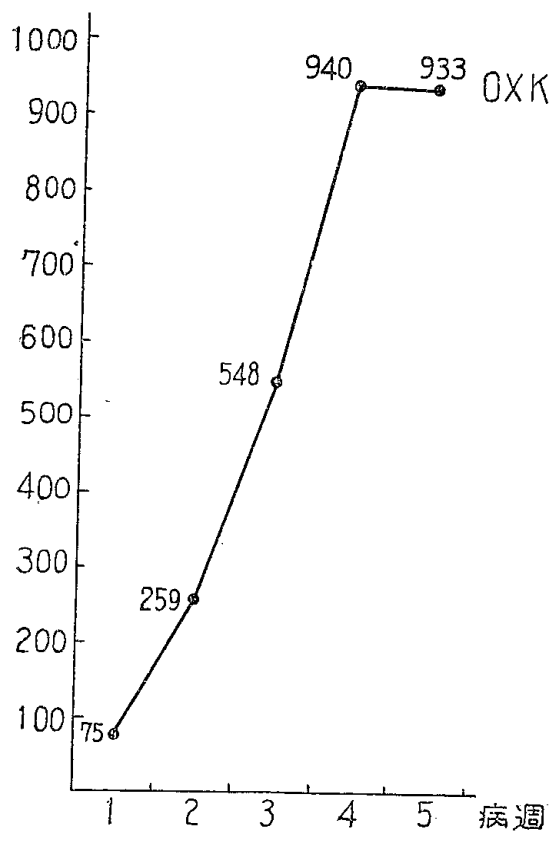

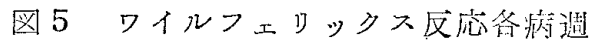
平均值の推移

第 10 表 尿 Urobilinogen

\begin{tabular}{|c|c|c|c|c|c|c|c|c|c|c|c|c|c|}
\hline $\begin{array}{c}\text { 病 } \\
日\end{array}$ & 2 & 3 & 4 & 5 & 6 & \begin{tabular}{l|l}
7 & 8
\end{tabular} & \begin{tabular}{l|l}
8 \\
8
\end{tabular} & 9 & $00_{i}^{1}$ & 112 & 13 & 814 & 15 \\
\hline 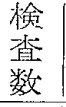 & 1) & 3 & 2 & 4 & 310 & $\begin{array}{lll}0 & 4\end{array}$ & 3 & & \begin{tabular}{l|l}
6 & 1
\end{tabular} & 10 & 1 & 1 & 1 \\
\hline & 0 & 0 & 0 & 4 & & $\begin{array}{l}82 \\
\end{array}$ & 2 & 3 & 30 & 0 & & 0 & 0 \\
\hline 5 & 1 & 3 & 2 & 0 & 1 2 & $\begin{array}{ll}2 & 2\end{array}$ & 1 & 3 & $\begin{array}{lll}3 & 1\end{array}$ & $\begin{array}{l}1 \\
1\end{array}$ & 1 & 1 & 1 \\
\hline & 0 & 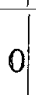 & & & & & 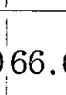 & & & & & & \\
\hline
\end{tabular}

第 11 表 Thymol 混濁試験

\begin{tabular}{|c|c|c|c|c|c|c|c|}
\hline 病弾位 & 1 & 2 & 3 & 4 & 5 & 6 & 7 \\
\hline 1 & 2 & & & & & & \\
\hline 2 & 1 & & & & 1 & & \\
\hline 3 & & & & & 1 & & \\
\hline 4 & & & & & 1 & & \\
\hline 5 & & 1 & & & 1 & & 1 \\
\hline 6 & & & & & 1 & & \\
\hline 7 & & 2 & 1 & & 1 & 1 & \\
\hline 8 & & & & & 1 & & \\
\hline 9 & & & & & & & \\
\hline 10 & & & & & 1 & & \\
\hline 11 & & & & & & & \\
\hline 12 & & & & & & & \\
\hline 13 & & 1 & & & & & \\
\hline
\end{tabular}

第 12 表 Thymol 䋈状試駼

\begin{tabular}{l|l|l|l|l|l|l|l}
\hline 病 & 1 & 2 & 3 & 4 & 5 & 6 & 7 \\
\hline- & 2 & 1 & & & 1 & & \\
\pm & 1 & & 1 & & & & \\
+ & & & & & 1 & & \\
+4 & & & & & 1 & & 1 \\
H & & & & & & 1 & \\
H & & 3 & & & 5 & &
\end{tabular}

第13域 Kunke1 氏硫酸亞鉛試蹒

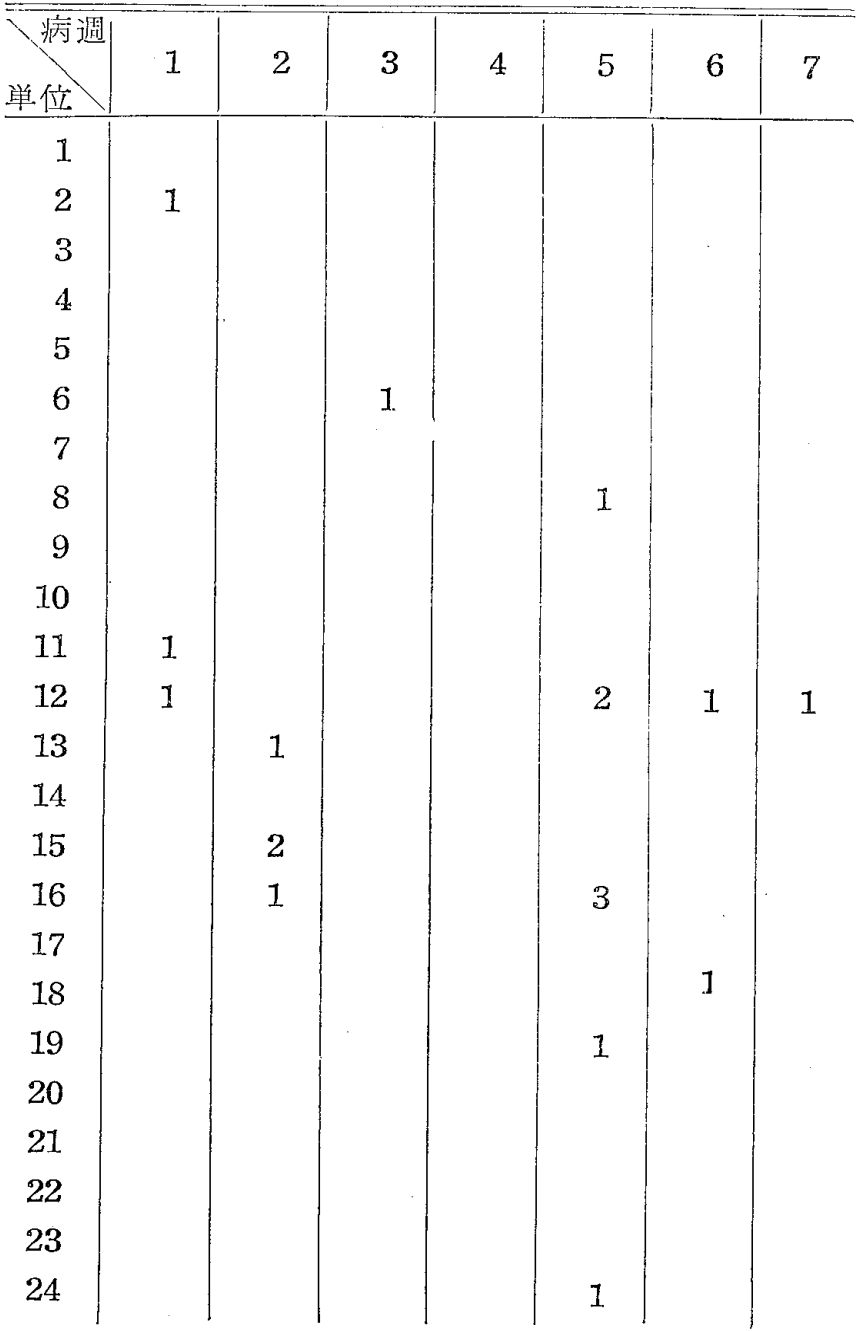

\section{6. 心電図所見（表16）}

13例の患者について経過芼追つて四脖誘導のみについ

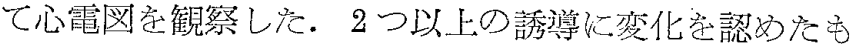

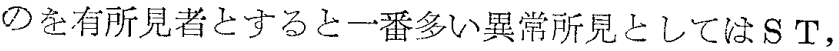

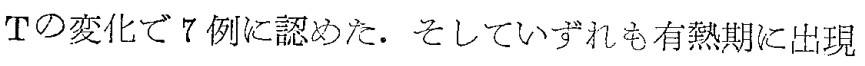
し，下熱するに到り正常に復した。洞頻脈は 6 例に認め 有熱期に出現し下熱すると正常に復した。.Pの扇平化は

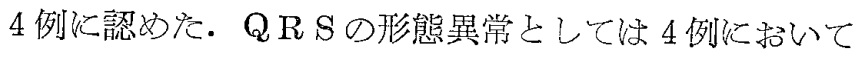
R III゙けの結節字認めたが各期岚通じ出現したから本来 のものであると考えられる，PQ，QTの㭙間の延長， 
第14表 セフアリンコレステロール絮状試験

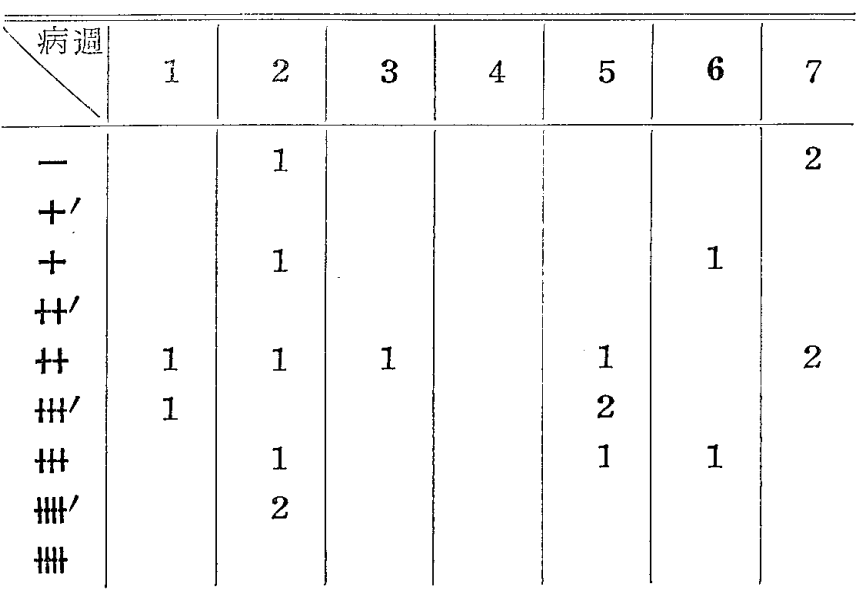

第 15 表 ブロムサルフアレイン試験

\begin{tabular}{r|l|l|l|l|l|l|l}
\hline \hline 病週 & 1 & 2 & 3 & 4 & 5 & 6 & 7 \\
\hline 0 & & & & & & 1 & 1 \\
5 & & 1 & & & 1 & & \\
10 & 1 & & & & & & \\
15 & 1 & & & & & & \\
20 & & & & & & & \\
25 & & & & & & & \\
30 & & & & & & & \\
35 & & & & & & & \\
40 & & 1 & & & & &
\end{tabular}

短縮涊認めなかつた。

\section{IV 治 療}

\section{1. 抗生物盺の使用法とその効果}

1949，1950年に本疾患がリケッチア症であるという推 定のもこ《PAB Aの試験学してみよう己思つたが入手 出来なかつたので曹ら刘症療法を行つた。解熱倣に上り 発汗し，一眭的に体温性多少下降与当尚自覚症も殆んご 緩解されず病期も短縮されなかった．1951年秋からオー レオマイシン，テラマイシン，クロロマイセチンなどの

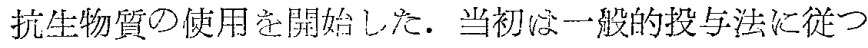
て成人の場合初回量起 $0.75 \mathrm{~g}$ 又位 $0.5 \mathrm{~g}$ 己乙 4 㭙間每义 泾 6 時間毎飞 $0.25 \mathrm{~g}$ ずつ, 全量 $1.5 \mathrm{~g}$ より $4.0 \mathrm{~g}$ 投与し た。殆んざ投薬㣪14時間〜15㭙間で分利解熱し自覚症状，

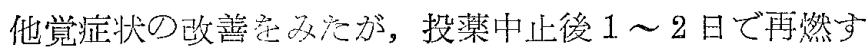
号例が多くみられ\%。乙の再燃という現象のため投与

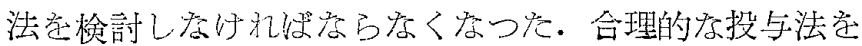

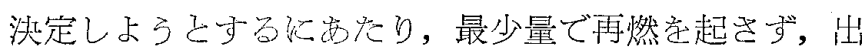
来るだけ短期間に治愈に導くこ己を目標にしな。投与例 の中で 1 例でも再燃起起したの综，不適当な投与法之 して使用法を变更して行つ炎。そして出来うれ站全量学
第 16 表 心電図所見病的，○正常

\begin{tabular}{|c|c|c|c|c|c|c|c|c|c|}
\hline $\begin{array}{c}\text { 所見 } \\
\text { 患者名 }\end{array}$ & 性 & $\begin{array}{l}\text { 年 } \\
\text { 齡 }\end{array}$ & $\begin{array}{c}\text { 病 } \\
\text { 日 }\end{array}$ & $\begin{array}{l}\mathrm{P} \\
\text { 波 } \\
\text { 扁 } \\
\text { 平 } \\
\end{array}$ & $\begin{array}{l}\mathrm{P} \text { 延 } \\
\mathrm{Q} \text { 辰 } \\
\text { 間 } \\
\end{array}$ & 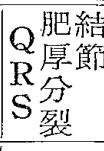 & 降 & 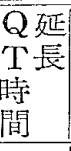 & $\begin{array}{l}\text { 洞 } \\
\text { 頻 } \\
\text { 脤 }\end{array}$ \\
\hline T. T. & $\hat{\delta}$ & 44 & $\begin{array}{r}8 \\
76\end{array}$ & (7) & 0 & 0 & (7) & 0 & 0 \\
\hline & & & & & 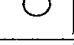 & & 0 & U & 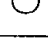 \\
\hline & & & 7 & 0 & 0 & 0 & A & $O$ & \\
\hline $\mathrm{S} F$ & 0 & & 11 & 0 & 0 & 0 & (2) & 0 & 3 \\
\hline & F & & 15 & 0 & 0 & 0 & 궁 & 0 & 6 \\
\hline & & & 9 & 0 & 0 & 0 & 0 & 0 & 0 \\
\hline & & & 5 & 0 & 0 & 0 & (7) & 0 & 0 \\
\hline T. H. & $\hat{o}$ & 30 & 14 & 0 & 0 & 0 & 10 & 0 & O \\
\hline & & & 44 & 0 & 0 & 0 & 0 & 0 & 0 \\
\hline$H$ & & & 5 & - & 0 & 0 & - & 0 & 0 \\
\hline 1. & $\vec{\gamma}$ & & 16 & () & 0 & 0 & 0 & 0 & 0 \\
\hline & & & 7 & 0 & 0 & 0 & 0 & 0 & 0 \\
\hline K. H. & o & & 12 & ? & 0 & 0 & 0 & $O$ & 0 \\
\hline & & & 5 & 0 & 0 & 0 & (2) & 0 & 0 \\
\hline Y. H. & So & 34 & 13 & 0 & 0 & 0 & 0 & 0 & O \\
\hline $\mathrm{M}$ & $\hat{1}$ & & 7 & 0 & 0 & 0 & 0 & 0 & 궁 \\
\hline 1V. $1 \mathrm{~N}$. & 0 & & 21 & 0 & 0 & 0 & 0 & 0 & 0 \\
\hline & $\hat{1}$ & & 2 & 0 & 0 & 0 & 0 & 0 & 0 \\
\hline IVt. & 0 & & 13 & 0 & 0 & 0 & 0 & 0 & 0 \\
\hline & & & 7 & 0 & 0 & 0 & (궁 & 0 & 0 \\
\hline o. S. & $\hat{o}$ & & 13 & 0 & 0 & 0 & 0 & 0 & 0 \\
\hline & & & 18 & 0 & 0 & 0 & 0 & 0 & 0 \\
\hline & & & 5 & 0 & 0 & 0 & 0 & 0 & 0 \\
\hline T. Y. & 우 & & 10 & 0 & 0 & 0 & 0 & 0 & 0 \\
\hline & & & 21 & $\bigcirc$ & 0 & 0 & 18 & 0 & $O$ \\
\hline & & & 8 & 0 & 0 & 0 & 0 & 0 & 웅 \\
\hline O. R. & o & 42 & 23 & 0 & 0 & 0 & 0 & 0 & 0 \\
\hline & . & & 4 & 0 & 0 & 0 & 0 & 0 & (2) \\
\hline 1. & F & & 13 & 0 & 0 & 0 & 0 & 0 & 0 \\
\hline & 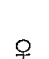 & & 6 & 0 & 0 & 0 & 0 & 0 & 0 \\
\hline & $F$ & & 26 & 0 & 0 & 0 & 0 & 0 & 0 \\
\hline
\end{tabular}

$1 \mathrm{~g}$ を起えないょ了《土夫した。（表17）

投与法学検討する3ち，投与量が多くても治療日数が

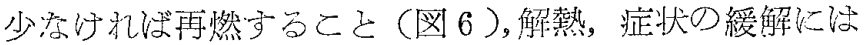

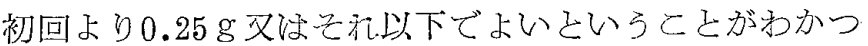
てきた。投薬日数络治療開始病日《影響され，緩解期飞 近く治療学開始与れば当然治療日数添短縮される。上 のような経験により治療開始日の如何学問わずオーレオ

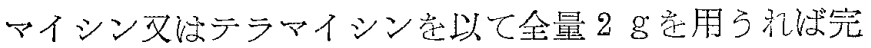


第 17 表抗生物質投与法と再然の有無

\begin{tabular}{|c|c|c|c|c|c|c|}
\hline 患者番号 & 抗 生剂 & 初回 $\mathrm{mg}$ & 維持量 mg & 投与間隔 & 全 量 $\mathrm{mg}$ & 再 㦓 \\
\hline 1 & $\mathrm{CM}$ & 750 & 250 & 4 踏間 & $1,500 \sim 3,000$ & + \\
\hline 2 & $\mathrm{AM} \quad \mathrm{CM}$ & 750 & 250 & $6 "$ & $1,500 \sim 3,000$ 攻び 4,000 & + \\
\hline 3 & $\mathrm{AM} \quad \mathrm{CM} \quad \mathrm{TM}$ & 500 & 250 & $6 "$ & $1,500 \sim 3,000$ & + \\
\hline 4 & AM $\quad$ CM $\quad T M$ & 1,000 & & & 1,000 & + \\
\hline 5 & $\mathrm{TM}$ & 1,000 & 1,000 & $24 \prime \prime$ & 2,000 & + \\
\hline 6 & $\mathrm{TM}$ & 1,000 & 250 & $24 \prime \prime$ & 1,500 & + \\
\hline 7 & $\mathrm{AM}$ & 500 & 500 & $24 \prime \prime$ & 1,000 & + \\
\hline 8 & $\mathrm{AM}$ & 250 & 250 & $6 "$ & $1,000 \sim 2,000$ & + \\
\hline 9 & $\mathrm{AM}$ & 250 & 250 & $12 "$ & $1,000 \sim 2,000$ & + \\
\hline 10 & $\mathrm{AM}$ & 250 & 250 & $24 \prime$ & 1,000 & + \\
\hline 11 & $\mathrm{AM}$ TC & 250 & 250 & $24 "$ & 2,000 & 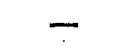 \\
\hline 12 & $\mathrm{TC}$ & 250 & 250 & $24 \prime \prime$ & 1,000 & 一 \\
\hline 13 & $\mathrm{TC}$ & 125 & 125 & $24 "$ & 1,000 & 一 \\
\hline 14 & $\mathrm{TC}$ & 2502 日 & 125 & $24 "$ & 1,000 & - \\
\hline
\end{tabular}

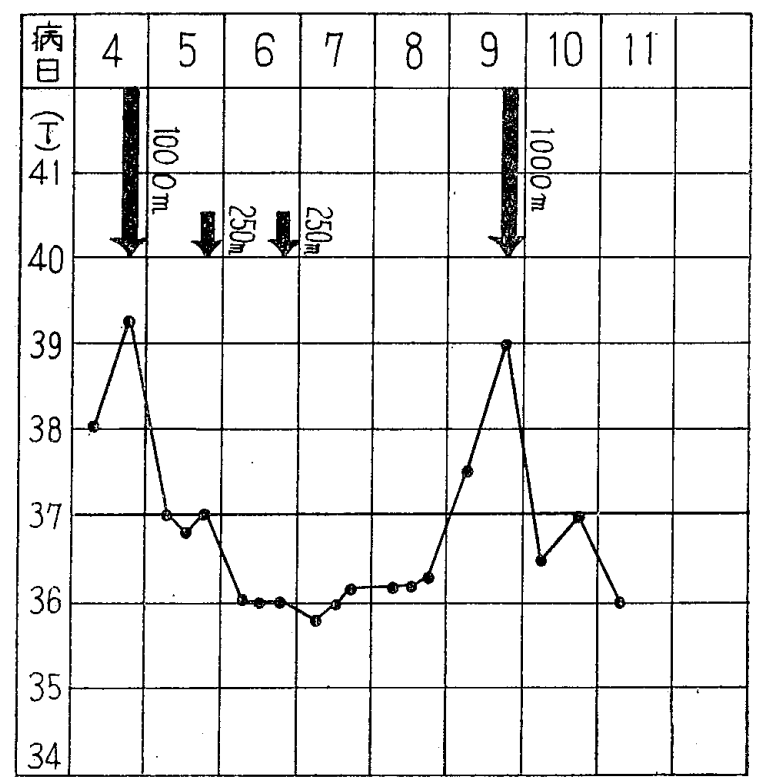

図 6 テラマイシン投与例

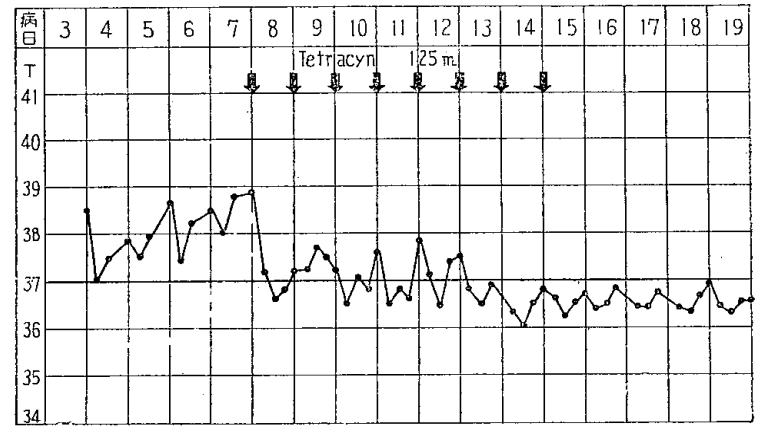

図 8 テトラシン投与例 1 日 1 回 $125 \mathrm{mg}$ 宛

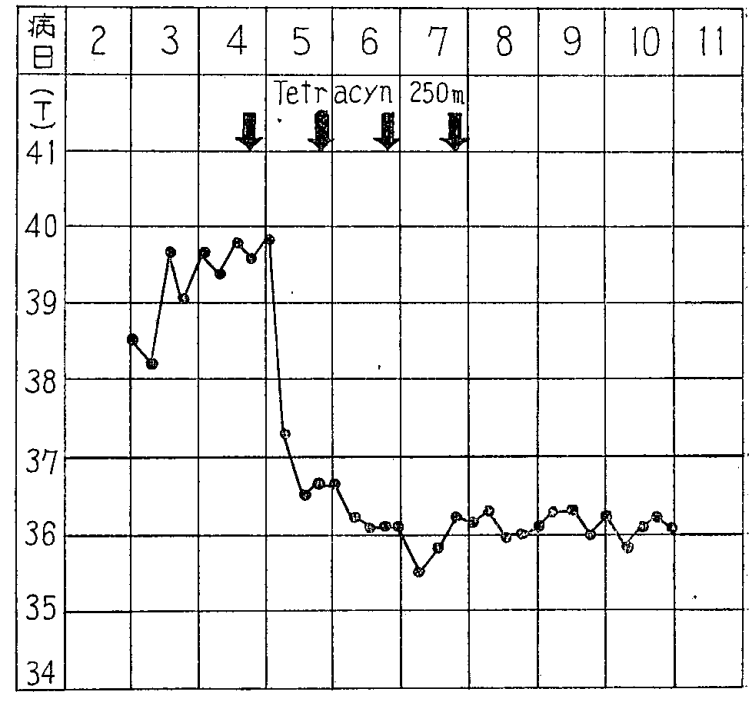

図 7 テトラシン投与例

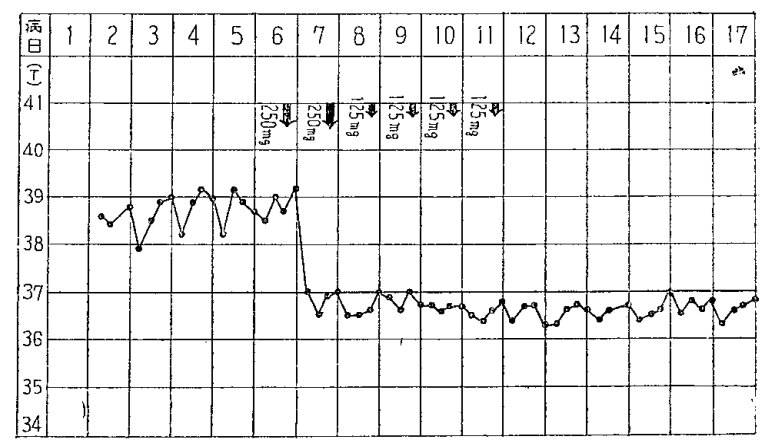

図 9 テトラシン投与例総量 I g 
(252)

1956 年 Vol. 7 Nos. $3 \cdot 4$

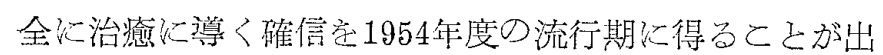
来た. 1955年度の流行期に入りテトランン安使用した。 使用例怡 9 例で文つたが全部雪然なく治愈した。它の中 1例㥙 1 日1回 $1 / 2$ カプセル $(0.125 \mathrm{~g})$ ずつ 8 日間, 全 量 $1 \mathrm{~g}$ 投与したが解熱稍渗散状で，自覚症注0.25 g 投与 例程著明《纺解熱しなかつた(図 8).1例《初めの2 日 間恬 $0.25 \mathrm{~g}$ ずつ 1 日 1 回使用，以後 $0.125 \mathrm{~g}$ ずつ 4 日 間，全量 $1 \mathrm{~g}$ ，治療日数 6 日間という方法安試みてみた

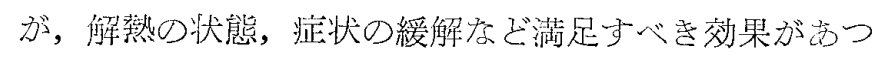
た（図 9)。乙れら抗生物質の投与の発疹に与方る影響

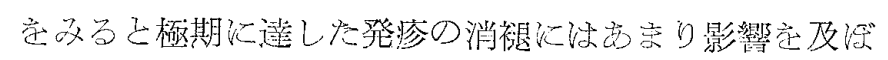
さないよ弓であるが（表 5)，初期の発疹代対しては急速

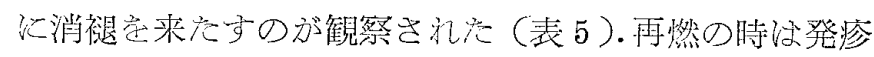

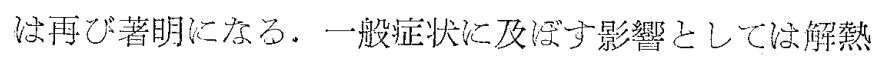
之共著明な恢復が齐られる。

\section{2. 考察}

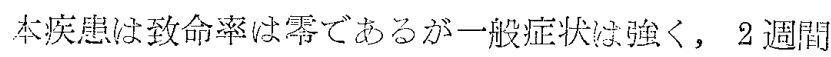

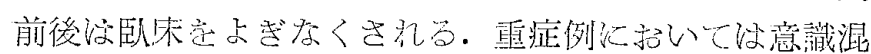
濁定伴うことがある。従つてて㣗に刘して合理的な治療 が望亲机る次第である.1日 1 回0.25 g投与, 全量 $1 \mathrm{~g}$ 法

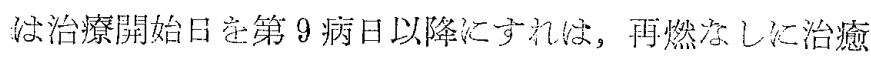

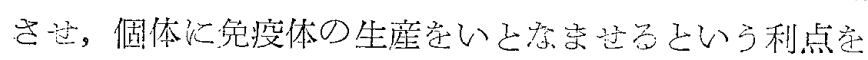

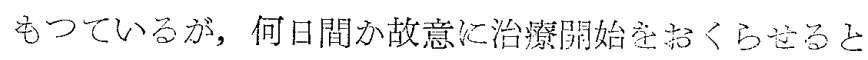
いうの賢明な方法ではない。こして従前の致命率は需

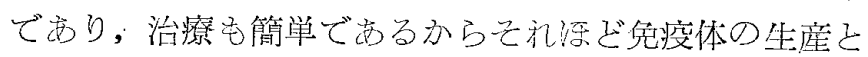
いうこと煌を用いる必要はないと考光られる０.125 $\mathrm{g}$ ずつ 1 日 1 回 8 日閒, 全量 $1 \mathrm{~g}$ 法注量も少く, 再燃

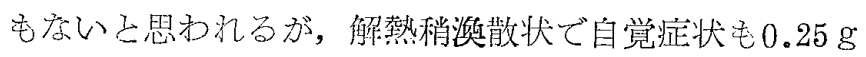
法深ざ速に消裉せず，治療日数隹や〉長くなる．以上の 点からその耐方主加味して病初の 1 ～ 2 日間 $0.25 \mathrm{gずつ}$ 24時閒每, 解熱綏解後每日 $0.125 \mathrm{~g}$ ずつ総量 $1 \mathrm{~g}$, 治潦

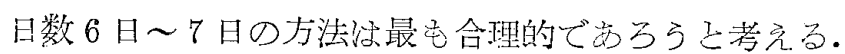

\section{V まとあ}

八文島飞冬期飞流行する発疹性熱性疾患で，俗以八文

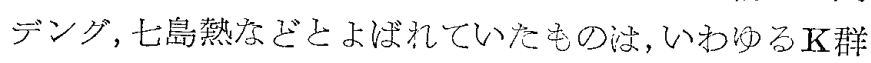

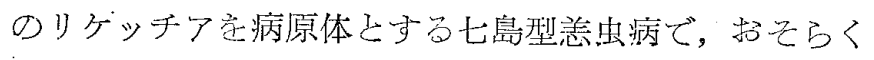
タテツツガムシがとれ等媒介し，臨休的には 1 ～ 3 週間 持続与る高熱, 著明な発渗, いわ的当刺口（皮膚の初発潰 瘍）の存在, Weil-Felix反出のOXK凝集価の上昇なる゙

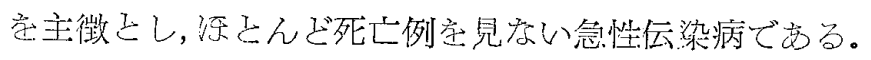

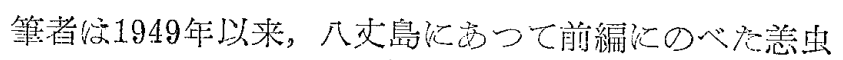
類の生態, 疫学的研焭亡平行し, 本症の臨床的小研究安 つジけて次のような点起明らかにしえた。

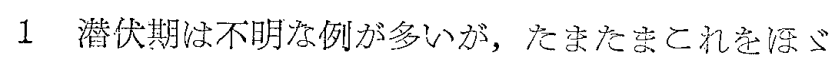

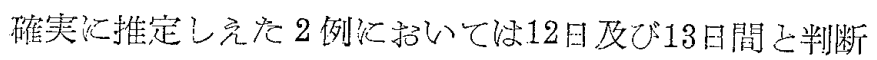
さ扎た。

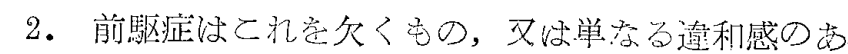
る程度のものが多い。

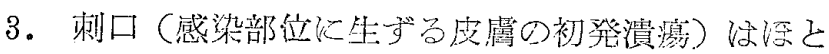

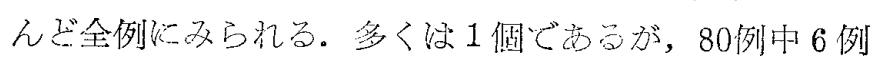

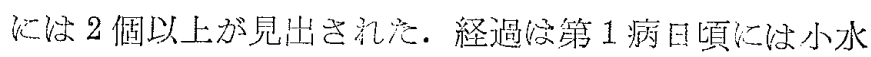

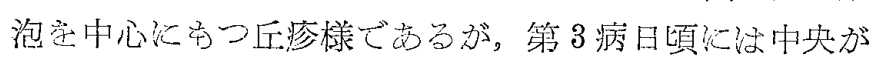

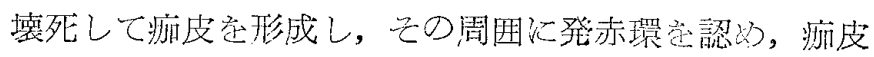

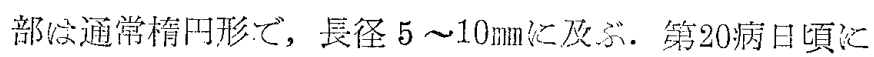

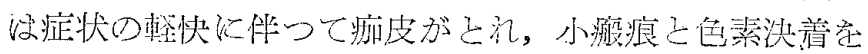

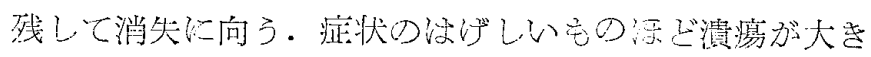
、傾向が品れる。

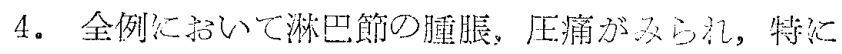
刺口の局所淋巴節飞相当したるのにてれが湆明である。

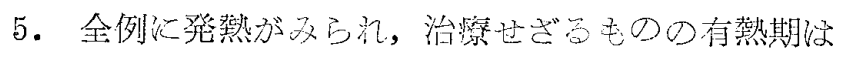
10 14日位である. 大多数が恶寒学以て発病し，利半数

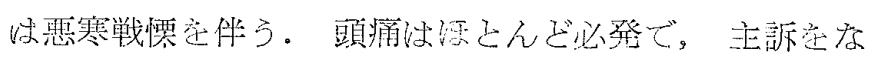

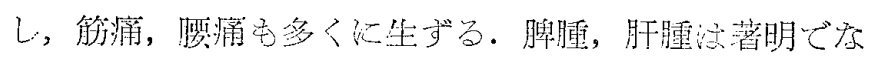
い. 消化系症状经不定で故尚。

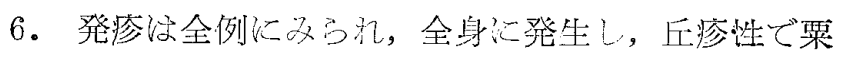

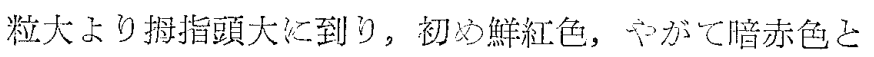

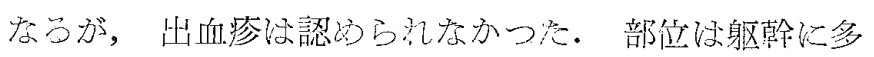
く，四肢では躯幹汇近い属側飞著明であるが，頭髮部や

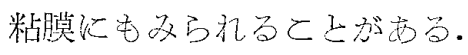

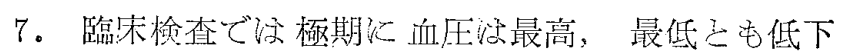

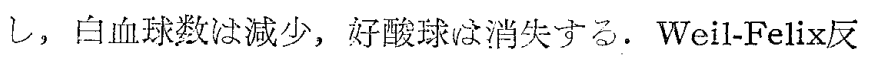

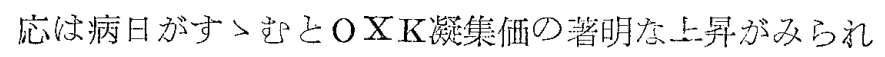

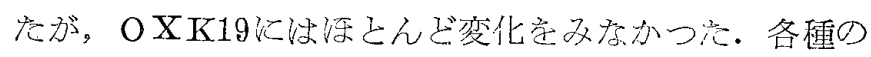

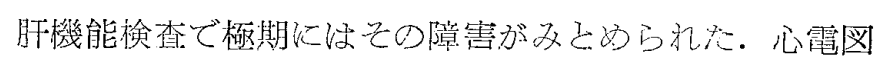
にも一眭的な変化の文万れた例がある。

8. 治蒸に注テラマイシン,テトラシン,オーレオマイ シン,クロロマイセチンな゙゙の抗染㧩の卓效が認められ

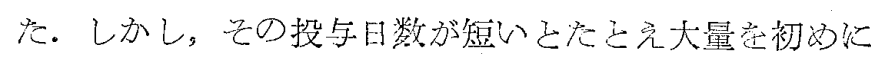
あたえてふ雨然が生じきすく，反対代少量です7日以上

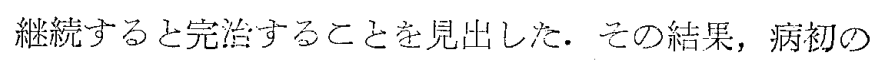
1〜2 日崔テトラシン, テラマイシン惁ざの 250mg 1 日 1 回, 解熱後その $125 \mathrm{mg} 1$ 日 1 回 $4 \sim 6$ 日間, 計 $6 \sim 7$ 日間の投与で䋓量約 $1 \mathrm{~g}$ 定以て最も合理的，経済的な治 療方式已考允る。

本研究に御指導を元を東大伝研, 北本治教授, 伎々学 助教授, 潼上正博士, 川村明義博士, 新潟大学桂重鸿教 授, 寺田博士, 東京都衞研, 新井養老膘士らの方々儿深 謝する。

(東北大 黑屋政斑教授)

\section{参考交献}

1）新井羕老 (1953)：七島熱, 日本伝染病学会雑誌, $27(7,8) ： 280 \sim 302$ ～- -2) 福佳定吉，小烟義男 
（1952）：三宅島の恙虫について (子報)，七島熱の調 查研究, 第 1 篇 $:$ 105 111。 -3) Fukuzumi, T. and Obata, Y. (1953) : On five species of trombiculid mites (Acarina) recovered in Miyakejima Island. Kitasato Arch. Exp. Med. 26 (1): 1 22. 4) 林滋生，鈴木猛，田中寬，緒方一喜 (1954)：タテ ッッガムシ Trombicula scutellaris Nagayo et al., の分布と人体答生性について, 衛生動物，5 $(1,2)$ : 66 67. 一5) 林滋生, 鈴木猛 (1954)：恙虫の生態に 関する研究 (II) Trombicula scutellaris Nagayo et al., 1921 の地表分布について, 衞生動物 $5(3,4)$ : 93 - 100. -6) 林滋生, 鈴木猛, 凷中寬, 寺邑誠袯, 上野庸治, 佐々学 (1953) : タテッッガムシ, ナンヨ ウッッガムシ及びアカッッガムシの未吸着幼虫の地表 分布について，七島熱の研究，第 3 篇: 61〜 74. 一7) 加納六郎 (1952)：伊豆七島の鼠について，七眗熱の 調查研究, 第1篇：111 113。 - 8) 桂重鸿 (1953): 恙虫病の臨床, 日本伝染病学会雑誌, $27(3,4)$. - 9）川村明羕 (1953)：七島熱の病原体について（第 2 報)。七島熱の研究，第 2 篇 : $34 \sim 37 .-10)$ 北岡正 見, 大久保薰, 高野窄一, 浅沼端 (1953) : 八丈島に 和ける七岛熱について一病原体保有者前に媒介者の㭘 索, 七島熱の研究, 第 2 篇: 29 34. - 11) Nagayo, M., Miyagawa, Y., Mitamura, T., Tamiya, T. and Tenjin, S. (1921): Five species of Tsutsugamushi and their relation to the Tsutsugamushi disease. Am. Jour. Hyg. $1(5 \sim 6): 569 \sim 590$. 12）佐々学, 加納六郎 (1950): 恙虫の研究 (1) Trombicula wichmanni の日本飞於ける発見，東京医事 新誌, 67 (4): 9 10. 一13) 佐々学, 加納六郎, 寺 邑誠祐 (1950) : 恙虫の研究 (2) 八文地方の恙虫飞 ついて, 東京医專新誌, 67 (10): 22〜23. -14) 佐 々学, 加納六郎, 林滋生, 熊田信夫, 三浦昭子, 佐藤 㨍慈, 浅沼靖 (1952) : 恙虫の研究 (23) 七島熱の調榃 研究, 徫生動物篇, 七島熱の調查研究, 第 1 篇 : 91 ～104. - 15) 佐々学, 林滋生, 川島源蔵 (1953) : 恙 虫の研究 (32) 新に八大地方の鳥類に見出された恙虫 について，東京医事新誌，70 (4) : 203 205. 一16) 佐々学, 小峰績, 川村明義, 三浦昭子, 林滋生, 鈴木 猛，目中寬 (1953) : 恙虫の研究 $(43)$ 八丈島産タテ ッッガムシ Trombicula scutellaris の人体吸着実騟, 七管熱の研究，第 2 篇：82８7．－17） Sasa, M. (1954) : Trombicula scutellaris Nagayo et al., 1921 and its relationship to the winter scrub typhus of Japan, together with systematic accounts for the four species of Tsutsugamushi discribed by $\mathrm{Na}$ gayo and others. Special number of the Jap. Jour. of. Sanitary. Zool. $4: 233 \sim 251 .-18$ ) 佐々 学 (1954) : 七泉型恙虫病 (scutellaris 系恙虫病) の 比較疫学, 七島熱の研究, 第 3 篇 : 45 52. -9) 佐 々学 (1955): 恙虫病の疫学, 第 14 回日本医学会総会 特別講演集，243～250. 一20）佐々学，三浦昭子，四 中寬, 上野佣治 (1955)： タテッッガムシ幼虫の集落 形成機序について, 衞生動物, 6 (2) : 135〜136。 21) Sasa, M. (1955) : Comparative epidemiology of Tsutsugamushi disease. Jap. Jour. Exp. Med.
24 : 335 361.一22) 佐及学, 林滋生, 田中寬 (1956): 日本産ツッガ虫幼虫火みられる地方的変異について, 日新医学，42 (3):439 450. -23) 鈴水猛, 目中

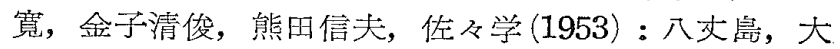
島の地表に和ける恙虫の発生状況の研究, 七島熱の研 究, 籍 2 篇, 65 78. -24) Suzuki, T. (1953)：Studies on the bionomic and chemical control of Tsutsugamushi (scrubtyphus mites) Part II. Trombicula scutellaris Nagayo et al., in Southern Kanto of Japan. Jap. Jour. Exp. Med. 24 : 181 197. 一25）鈴木猛，林滋生，緒方一喜，四中寛，佐 々学 (1953) : Trombicula scutlelaris Nagayo et al., の末吸着幼虫の行動及び日週活動について，七島熱の 研究, 第 3 篇, 53〜60. - 26) 立花次郎, 山口与四郎 井之川季雄, 池田和雄, 難波榢士, 岩崎綾子 (1953): 七島憼の疫学的観察 (第 2 報), 七島熱の研究, 第 2 篇, 1 11, 一27) 由中算, 佐々学, 上野廚治 (1955)： タテッッガムシ未吸着沏虫の呼気中炭酸方スによる興

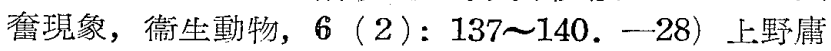
治, 田中寬, 佐文学 (1955) : 八丈島に扣けるタテッ ツガムシ幼虫の集団出現性とその等生機序についての 新知見, 衞生動物, $6(2): 133 \sim 134 .-29)$ 山口与 四郎瓜办 9 名 (1954)：七島熱の疫学的観察（第 3 報) 七島熱の研究第 3 篇, 1 5. - 30) 与謝野光活加 8 名 (1952)：七島熱の疫学的観察，七島熱の調查研究，第 1 篇, 9 39.

\section{Summary}

The author made three years' studies on trombiculid mites and Tsutsugamushi disease of Hachijo Island, about $350 \mathrm{~km}$ south of Tokyo. A total of 10 species of the mites were recovered from this island, and their seasonal and areal distributions were investigated. Two species were found to be epidemiologically important. Trombicula scutellaris which appears in winter and probably transmits Shichito-type Tsutsugamushi disease prevalent in this area, and Trombicula wichmanni which appears in summer and causes severe itches. Tsutsugamushi disease in this island was also investigated from clinical as well as from epidemiological points of view. This was characterised with its appearance in the winter season and with the extremely low mortality, differing from that in the classical endemic foci of northwest Honshu. 